\title{
Application of Whey Protein-Based Edible Films and Coatings in Food Industries: An Updated Overview
}

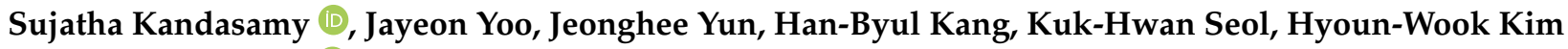 \\ and Jun-Sang Ham * (i)
}

Animal Products Research and Development Division, National Institute of Animal Science, Rural Development Administration, Wanju 55365, Korea; sujirda2019@korea.kr (S.K.); yjy1172@korea.kr (J.Y.); rsvped@korea.kr (J.Y.); khb1771@hanmail.net (H.-B.K.); seolkh@korea.kr (K.-H.S.); woogi78@korea.kr (H.-W.K.)

* Correspondence: hamjs@korea.kr; Tel.: +82-63-238-7366; Fax: +82-63-238-7397

Citation: Kandasamy, S.; Yoo, J.; Yun, J.; Kang, H.-B.; Seol, K.-H.; Kim, H.-W.; Ham, J.-S. Application of Whey Protein-Based Edible Films and Coatings in Food Industries: An Updated Overview. Coatings 2021, 11, 1056. https://doi.org/10.3390/ coatings11091056

Academic Editor: Stefano Farris

Received: 9 August 2021

Accepted: 28 August 2021

Published: 31 August 2021

Publisher's Note: MDPI stays neutral with regard to jurisdictional claims in published maps and institutional affiliations.

Copyright: (c) 2021 by the authors. Licensee MDPI, Basel, Switzerland. This article is an open access article distributed under the terms and conditions of the Creative Commons Attribution (CC BY) license (https:/ / creativecommons.org/licenses/by/ $4.0 /)$.
Abstract: The recent surge in environmental awareness and consumer demand for stable, healthy, and safe foods has led the packaging and food sectors to focus on developing edible packaging materials to reduce waste. Edible films and coatings as a modern sustainable packaging solution offer significant potential to serve as a functional barrier between the food and environment ensuring food safety and quality. Whey protein is one of the most promising edible biopolymers in the food packaging industry that has recently gained much attention for its abundant nature, safety, and biodegradability and as an ecofriendly alternative of synthetic polymers. Whey protein isolate and whey protein concentrate are the two major forms of whey protein involved in the formation of edible films and coatings. An edible whey film is a dry, highly interacting polymer network with a three-dimensional gel-type structure. Films/coatings made from whey proteins are colorless, odorless, flexible, and transparent with outstanding mechanical and barrier properties compared with polysaccharide and other-protein polymers. They have high water vapor permeability, low tensile strength, and excellent oxygen permeability compared with other protein films. Whey protein-based films / coatings have been successfully demonstrated in certain foods as vehicles of active ingredients (antimicrobials, antioxidants, probiotics, etc.), without considerably altering the desired properties of packaging films that adds value for subsequent industrial applications. This review provides an overview of the recent advances on the formation and processing technologies of whey protein-based edible films/coatings, the incorporation of additives/active ingredients for improvement, their technological properties, and potential applications in food packaging.

Keywords: packaging; dairy waste; active ingredients; milk proteins; mechanical and barrier properties

\section{Introduction}

Food packaging has grown significantly in recent years to include new functionalities and meet the demands in markets that constantly challenge the development of stable and fresh food products. The goal of packaging is to enable the food to be transported safely over long distances, protect the food from external factors and contamination, ensure the nutritional value and health during consumption, and provide consumers with information about the contents [1]. Hence, the packaging materials should possess reliable features, such as nontoxic, microbial stability, mechanical and barrier properties, appropriate sensory qualities, inexpensive production, and product compatibility [2].

To meet the above demands, there is a growing interest in packaging materials made using edible biopolymers (proteins, polysaccharides, and lipids) obtained from renewable sources or industrial by-products that are completely biodegradable, ecofriendly, and a greater alternative for petroleum-based materials widely used in food industries. The term coatings and films are frequently used as synonyms, although the only difference is their thickness. Films are thin layers of polymers initially molded as solid sheets and used to 
wrap a product, while coatings are applied exactly on the products' surface, typically by immersion in a polymer solution [3,4].

As a result, coatings are usually thinner than films and stay on the product during use and consumption. Edible films/coatings can be ingested together with the product and can thus be counted as food and as packaging [2]. The primary goal of edible films and coatings is to enhance the quality and extend the shelf life and safety of foods by limiting the transfer of moisture, gases (e.g., $\mathrm{O}_{2}$ and $\mathrm{CO}_{2}$ ), lipids, aromas, and oils from or into food [5].

For edible packaging, films or coatings are primarily produced using components of polysaccharides, proteins, and lipids used alone or together [6,7]. Within hydrocolloids, proteins serve as an excellent candidate to produce biodegradable films and coatings since they possess suitable mechanical, optical (transparency), and physical properties (flexibility and resistance). Moreover, they can act as barriers to oxygen, aromas, and organic compounds. Various protein materials, including casein, collagen, corn zein, fish proteins, ovalbumin, soy protein isolate, wheat gluten, and whey protein isolate have been verified $[8,9]$.

Milk proteins, such as casein and whey proteins (WP), offer several significant physical properties (e.g., water solubility and emulsifying ability) for successful functioning in edible films, in addition to their nutritional value [10]. The surplus availability of WP generates considerable interest in packaging industries allowing them to use as films/coatings on food surfaces to protect foods against degradation from chemicals or microorganisms, and thereby extend the shelf life and sustain high product quality. The mechanical and barrier properties of WP films are gaining more attention as they outperform polysaccharides and other protein-source-based films.

WP used in the manufacturing of films/coatings has certain remarkable features, such as appetizing nature and inherent biodegradability, appropriate mechanical barrier and optical properties, valorization, and the ability to include functional compounds. The disadvantages are the moisture barrier and few restrictions on the mechanical properties [11,12]. Cross-linking through physical, chemical, or enzymatic methods and blending plasticizers with WP can attain the desired properties [3].

WP-based edible films/coatings have already been applied in several food products, such as peanuts, walnuts, frozen salmon, fruits, and breakfast cereals, to improve the aroma, fat, moisture, and gas barriers [13]. Furthermore, incorporating active ingredients (e.g., antimicrobials, antioxidants, probiotics/prebiotics, and flavor) into WP films/coatings is a new trend in the industry targeting to provide health benefits to the consumers [14-16]. This review focuses on WP-based films/coatings formation and technologies used for processing, the incorporation of active ingredients, the technological (barrier, mechanical, surface, and optical) properties, and finally we summarize their applications in food industries.

\section{Whey Proteins}

It is well known that the dairy industry generates large volumes of liquid waste as a by-product during the casein coagulation process. This liquid, termed as dairy whey (DW) is a yellowish green colored, water-soluble protein by-product derived after casein extraction in cheese processing [17]. DW comes from all types of milk (cow, goat, sheep, and camel), although bovine DW is most common in the western countries, representing about $85-95 \%$ of the originating milk volume and contains around $55 \%$ of the total nutrients in milk [11]. Several innovative technologies are currently available to convert a large DW fraction into valuable products. One possible way to recycle DW is to exploit its protein content as a biopolymer source to create edible films/coatings in food [17].

DW acts as an excellent source for producing edible biopolymers in the packaging industry. The major organic fraction in whey is carbohydrate (lactose), followed by proteins, minerals, lactic acid, and lipids [1]. Whey proteins (WP) account for nearly $15-20 \%$ of the total milk proteins and are the most economically and technologically interesting fraction in whey. Generally, WP comprises five major fractions, including 50\% $\beta$-lactoglobulin 
( $\beta$-Lg), 20\% $\alpha$-lactalbumin ( $\alpha$-La), 15\% glymacropepetide (GMP), $10 \%$ immunoglobulin (Ig), and $8 \%$ bovine serum albumin (BSA). In addition to these, WP comprises some low abundance fractions (about 10\%): lactoferrin (LF), lactoperoxidase (LP), proteose peptones (PP), osteopontin (OPN), and lysozyme (LZ) [4,12]. The composition of WP varies depending upon the cheese type, production process, coagulation method (acid or enzyme), milk origin (bovine, ovine, or caprine), feeding regime, and lactation stage. These variations significantly impact the emulsification and other functional properties $[3,17]$.

WP are compact secondary, tertiary, or quaternary globular molecules with various combinations of cross-sulfur bonds and are heat labile, dephosphorylated, and less sensitive to calcium. Monomeric $\beta$-Lg is a small globular protein with a defined secondary and tertiary structure containing 162 amino acids, including five cysteine residues, of which four cysteines form two S-S bonds. The remaining one (Cys 121) retains a free thiol group that lies hidden in center of the native $\beta-\operatorname{Lg}$ structure and is decisive for film formation [12].

As the most abundant fraction in whey, $\beta$-Lg is responsible for gel formation and aggregation behavior in the WP formulation. $\alpha$-La is the second most abundant fraction in whey and is a small acidic protein containing four S-S bonds and calcium ions to maintain the tertiary structure and provide stabilization against denaturation [18]. BSA is the largest protein fraction with an alpha-helical structure containing 17 disulfide bonds and one free thiol [19].

The WP retains several functional values for human health. WP are also termed as "fast" proteins, since they migrate quickly from the stomach to small intestine, an effect considered because of the high amounts of branched-chain amino acid (BCAA) content (isoleucine, leucine, and valine) present in $\beta-\mathrm{Lg}$. The consumption of WP demonstrates several benefits unavailable in other protein sources (soy and egg). Both animal and human studies have recommended WP and its components to maintain lean body mass in energyrestricted diets, providing cardiovascular health benefits, antioxidant, antimicrobial and antiviral activities, immune-modulating activity, and anticancer activity $[4,17]$.

\section{Whey Proteins as Coating Materials}

The worldwide production of WP has risen drastically by the advancements in membrane and ion exchange techniques, making it simpler to recover WP with preferred and suitable functional qualities (acid stability, gelation, film-forming efficiency, and aeration) and emulsification characteristics [20]. Whey is commercially produced either as a fresh pasteurized liquid or in condensed forms (depending upon their concentration): whey protein concentrates (WPC, 35-80\% protein), whey protein isolates (WPI, $>90 \%$ protein), whey hydrolyzates, lactose-reduced whey, and demineralized whey. The composition of protein fractions and degree of purity varies with the pretreatment step and filtration techniques.

Generally, ultrafiltration, diafiltration, electrodialysis, gel filtration, ion-exchange chromatography, and reverse osmosis processes are routinely applied to WP recovery [9]. WPC are produced through the ultrafiltration process by the selective removal of highmolecular-weight materials from whey permeate [21]. WPC contains minimal amounts of fats and cholesterol but is rich in bioactive compounds compared to other commercial whey formulations. WPI are prepared by processing WPC using an additional ion-exchange chromatographic step to remove minerals and lactose [10].

WPI are rich in protein contents but have fewer bioactive compounds. Both WPC and WPI fractions can be converted into a dry form using the spray-drying process. Both these fractions meet suitable characteristics for application in food viz., high amino acid and protein contents; low-calorie, fat, and sodium contents; lack of pathogens and toxic metabolites; biocompatibility and generally recognized safe status; ready availability; and low-price [17]. Of the concentrated whey products, WPC and WPI are the most widely used as coating materials. 


\section{Formation of WP-Based Films/Coatings}

WP edible film is principally a dry, highly interacting polymer network with a threedimensional gel-type structure. Regardless of film-formation techniques, the final films can result in a spatially reorganized gel arrangement that includes all the additional filmforming agents [13]. WP-based films are achieved through the casting method in which the film solution is poured onto the flat surfaces to produce a dried gel and then applied as a wrapping on the food products.

While for WP coatings, the food products are typically immersed into the film-forming solution until a specific time period ( $30 \mathrm{~s}$ or $1 \mathrm{~min}$ ) to ensure complete exposure of the food surface with good adherence and perfect integrity, and finally air-dried [3,15]. Both WPbased films and coatings are flexible, colorless, odorless, and transparent. Compared to other film-forming polymers, WP contains some distinguishing features, i.e., amphiphilic nature, conformation, denaturation, and electrostatic charges. Factors including the charge density and hydrophilic-hydrophobic balance can modify the WP conformation, as these factors will eventually define the physical and mechanical properties of films/coatings [1,20].

The native WP cannot be considered as a good adhesive polymer candidate due to its compact globular structure and relatively small molecular size. Nevertheless, the globular structure can be reformed into relatively linear structures and later into irreversible aggregates through a thiol-disulfide exchange under certain conditions. Native WP can also produce coherent films, where the film formation depends on low-energy bonding like electrostatic interactions, hydrogen bonding, or van der Waals force [12].

The formation of WP-based films and coatings can be generally divided into several steps, including the dissolution of WPC or WPI (5-12\%) in distilled water, and adjustment of the solution's $\mathrm{pH}$ (either 7 or 8 ), or without adjustment, and subsequent heating $\left(80-90^{\circ} \mathrm{C}\right.$, 10-30 $\mathrm{min}$ ) for protein denaturation [20]. Other ingredients can be added before or after heating, based on the compatibilities between them. Components that can tolerate heat (prebiotics, starches, and blends) are included in an early stage of process, while heatsensitive ingredients (antioxidants, antimicrobial compounds, and probiotics) are included after heating [15].

Even though several heat treatment methods are feasible for gel formation, denaturation is the most applied technique to form coherent films. In native WP, most of the hydrophobic and $\mathrm{SH}$ groups are buried in the center of protein molecule. Denaturation exposes the functional and hydrophobic groups of WP to form a three-dimensional chemical network that promotes intermolecular S-S bonding and hydrophobic interactions in drying. WP films produced without heat treatment easily break into tiny parts during drying due to food intermolecular interactions $[3,20]$.

The thermal denaturation process occurs in a two-step transition at $\mathrm{pH}$ 6.0. The first step begins at above $40{ }^{\circ} \mathrm{C}$, where $\beta$-Lg dimers dissociate into monomers. Denaturation at beyond $65^{\circ} \mathrm{C}$ unfolds the $\beta$-Lg molecule and exposes hydrophobic and thiol groups, which relate to the build-up of smaller aggregates with either $\beta$-Lg or other thiol-containing proteins. In a second step, these smaller aggregates interact to produce high-molecularweight irreversible aggregates [10,12].

Furthermore, the free sulfhydryl groups promote the denaturation process by splitting the intramolecular disulfide bonds in $\alpha$-La and other WP. The temperatures required for irreversible denaturation of $\beta-\operatorname{Lg}$ and $\alpha$-La are 69 and $80^{\circ} \mathrm{C}$, respectively [1]. $\beta$ - $\mathrm{Lg}$ performs a key role in the polymerization of WP, which defines the degree of denaturation in WP. In addition, the rate of aggregation is also affected by the free sulfhydryl groups existing in $\beta$-Lg alone. Nevertheless, the impact of the $\mathrm{pH}$, salt, sugar, and protein levels on the thermal behavior of $\beta-\operatorname{Lg}$ needs to be considered [18]. The thermostability of $\beta-\mathrm{Lg}$ monomer was higher at $\mathrm{pH} 3.0$ and lower at $\mathrm{pH} 7.5$ due to the increased reactivity of thiol groups produced by dissociation under alkaline conditions [12].

WP films are eventually derived from gels through dehydration after forming heator cold-set gel. A conventional dehydration method is to dry under ambient conditions, usually between $21-23{ }^{\circ} \mathrm{C}$, and $50 \%$ relative humidity ( $\mathrm{RH}$ ). Nevertheless, the handling of 
the drying practice is critical while applying edible coatings onto foods, as quick drying alters the characteristics of film to be thinner, stiffer, and less flexible [3]. Modifying the drying rate, temperature, and humidity significantly affects the drying method and final film properties.

Reduced drying temperature from 25 to $5{ }^{\circ} \mathrm{C}$ in WP emulsion films containing beeswax increased the solubility and reduced the water vapor permeability (WVP) [22]. Likewise, drying at $95{ }^{\circ} \mathrm{C}$ and $30 \% \mathrm{RH}$ resulted in thin, stiff, robust, and less extendable films with a significant reduction in WVP compared to films dried at $21{ }^{\circ} \mathrm{C}$ and $50 \% \mathrm{RH}$ [23]. WP films dried in the microwave for $5 \mathrm{~min}$ showed a significant improvement of elongation and tensile strength values on a shorter period, while WVP remained similar to air-dried films [24].

Currently, numerous methods have been utilized to produce edible WP films/coatings, viz. casting, dipping, extrusion, enrobing, fluidization, foaming, spraying, and UV polymerization. Monitoring the processing conditions is crucial, as modifications in handling environments can vary the kinetics and reaction mechanisms included in film formation $[3,20]$. To be considered edible, the WP film-formation methods must remain suitable to hold foods with regarding changes in $\mathrm{pH}$, salt levels, heat, enzymatic variation, drying, usage of solvents, and other chemicals. In addition, plasticizers and further additives must also go well together with the biopolymer [13].

\section{Technologies in Processing WP Films/Coatings}

Adhesion (interaction between polymer and substrate) and cohesion (interaction between polymers) are the two main interactions that influence film formation and their properties. Cohesion relates to polymer qualities, such as the molar mass, polarity, and chain structure $[10,25]$. Edible protein films can be formed through two discrete methods viz. wet and dry processing. The wet process is the most common and traditional method, also termed as solvent casting. This method is ideal for applying coatings in fluid mode by completely brushing, dipping, or spraying onto food products. In the dry processing method, which has gained more attention currently, films made by extrusion and compression-molded at lower water contents make use of the thermoplastic properties of polymers [13].

\subsection{Wet Process/Solvent Casting}

Wet processing or solvent casting are commonly employed methods to make thin layer films. Casting is widely utilized in scientific works concerning formulation evaluation as it serves as an effective and cost-efficient way to ascertain the properties of film-formation. In particular, the solvent casting of WP films/coatings can be done through equipment existing in the research lab to pilot scale [12].

To produce films by solvent casting, at first the proteins are dissolved using a solvent that may be water, alcohol, or a mix of different solvents. Incorporating plasticizers, polysaccharides, lipids, or emulsifiers and their homogenization occurs at this phase [13]. The addition of plasticizers is mandatory to avoid fragility in protein films produced by excess cross-linking in the protein network; however, the compatibility between all film constituents must be counted as they wholly control the properties of final film [25].

The earlier step was followed by an adjustment of $\mathrm{pH}$ if mandatory, or initiation of cross-linking in protein, particularly by heating to improve film formation. The heat treatment can be done earlier, later, or during the coating process. The protein film is finally made by spreading the film solution manually onto a Teflon plate or petri dish surface and letting the solvent evaporate. The coating is formed on the food surface by dipping, spraying, or enrobing the film solution before solvent drying [13,26]. On a larger-scale level, WP films with fixed thicknesses are produced mechanically in batch or continuous coaters [27].

The properties of the final film are affected by the composition and process employed at each stage of film preparation. Consequently, materials produced through wet processing 
exhibit various functional traits, such as the protein levels and $\mathrm{pH}$ of the solution, the type of additives and solvents employed, and drying specifications, like the temperature and drying rate. Furthermore, the choice of drying procedures from ambient conditions to traditional drying through hot-air, infrared, or microwave also influences the final film properties [12].

Another significant factor that needs to be considered is the post cross-linking in WP films/coatings during storage. Schmid et al. [28] stated that changes in molecular interactions in WP films appear even after film formation and drying. A considerable reduction in oxygen permeability $(\mathrm{OP})$ has been influenced by alterations of covalent and non-covalent bonds among the polypeptide chains during storage. Crosslinking by disulfide bonds and hydrogen bonds are the main interactions in storage that decrease OP to lower levels following initial protein-film formation.

\subsection{Extrusion and Compression-Moulding}

Extrusion and compression-molding are well-known commercial methods applied to develop films and plastic granules. Before extrusion, transparent, flexible WP edible films undergo a thermal-compression molding stage, an eminent step with a less expensive method and time-consumption. The extruded WP films can be produced on a mass scale as pouches to serve various foods and dry ingredients [13].

In solvent casting, solvent removal is a time-consuming and energy-expensive step, owing to the price and maintenance of the drying oven. Instead, extrusion is a quicker and energy-efficient process that reduces the cost of production on biopolymers for competing against synthetic polymers. Thermoplastic extrusion is an interesting mode to make protein casings and films without solvent addition and removal. During continuous extrusion, the heat supply and energy input produced by friction among the screws melt the raw material mass, turn it formable, and push it across the extruder die into a preferred form [12].

The thermoplastic behavior of certain proteins has not been widely investigated in film production. However, the extrusion process entails the thermoplastic behavior of raw material. As proteins cannot exhibit thermoplastic behavior by nature, alteration in formulation through the addition of plasticizers and chemical additives seems necessary for protein extrusion and extensively investigated for WP $[12,29,30]$. Hernandez-Izquierdo and Krochta [31] employed glycerol (46-52\% on a dry basis) as a plasticizer to develop clear, flexible, extruded, and consistent WP sheets.

Compared to heat-denatured films in solvent casting, configuration and operation conditions of extruder enabled the heat denaturation and cross-linking of WP sheets formed with similar or improved mechanical properties. The amount of plasticizer did not affect the elongation of extruded films and hold values greater than of solvent casting films. Higher tensile strength was also obtained [13].

The thermoplastic behavior of WP extruded sheets aided them to be compressionmolded to produce heat-sealed or thin films. Compression-molded WP films plasticized with water were insoluble and more brittle than glycerol plasticized films [32]. Moreover, the glycerol levels ( $40 \%$ to $50 \%$ ) improved the elongation from $85 \%$ to $94 \%$, whereas the tensile strength declined to 4 from $8 \mathrm{MPa}$. Despite favorable outcomes, the characteristics of extruded and compression-molded WP film need to be further investigated [27,29].

Extensive research on solvent casting and drying polymerization along with the impact of processing conditions (pressure, temperature, and time) has been performed because of their direct impact on protein denaturation via unfolding their globular structure that stimulates interaction and entanglement among protein chains. On the other hand, different cross-linking methods, like chemical, enzymatic, or irradiation, are also reported to enhance film formation $[7,13]$. 


\section{Modification/Improvement of WP Edible Films and Coatings \\ 5.1. Protein Type and Concentration}

Denatured WP is broadly employed as a film base. In films/coatings produced with denatured WP, both hydrogen and disulfide bonds play a principal role, while, with native WP, hydrogen bonds alone contribute to the development of film/coating. Denatured WP films are insoluble in nature, whereas native WP films are completely water-soluble. The solubility of denatured WP films decreases under increased heating temperature and duration [20]. Denatured WP films exhibit higher tensile values than native films; however, WVP remains identical. Increased time and temperature of film-forming solutions produces films that are firmer, robust, and more extendible. The OP in denatured WP films was lower than for native WP films. These findings conclude that covalent cross-linking produced by heat denaturation in DW proteins is liable for insolubility, increased mechanical resistance, and $\mathrm{O}_{2}$ barrier properties of the film, without altering the films WVP $[20,26]$.

\subsection{Structuring Agents}

Concerning the potential application of pure WP films/coatings, the mechanical and barrier properties of transparent films are superior to polysaccharide films. Nevertheless, pure WP-based films have certain limits regarding their mechanical characteristics. The molecular weight of WPI in denatured WP films has a strong influence on the brittleness property. Edible films produced using WPI have demonstrated excellent oxygen and aroma barriers and poor mechanical properties. As a result, the formulation of WP-based films/coatings mainly requires some additional structuring agents at a lower level, e.g., plasticizers for evading brittleness, emulsifiers for stabilizing base emulsion, lipids for increasing WVP, and polysaccharides for improving barrier properties $[1,3]$.

\subsubsection{Plasticizers}

A plasticizer is defined as a low molecular mass, non-volatile agent added with polymers to alter the physical and/or mechanical properties of that material. The most frequent food-grade plasticizers are monosaccharides or disaccharides, polyols, lipids, and water. Plasticizers are usually included in the formation of edible WP films/coatings, as pure WP films are typically fragile and rigid because of extensive interactions among the polymers [33]. The addition of plasticizers is essential for protein-based films to decrease the interaction between protein polymers, thereby, enhancing the flexibility, elongation, toughness, and tear strength of the film [10]. Depending upon the type and concentration of plasticizers, increased film flexibility is also associated with increased WVP, which is undesirable for dietary applications $[25,26,33]$.

Edible WP-based films/coatings (mainly from WPI) mostly involve plasticizer content typically in the levels of $10 \%$ to $60 \%(w / w)$. Nevertheless, these levels rely on the selected film properties and plasticizer type. The proportion of plasticizers in films produced using WPCs as a protein source are required at lower amounts since the non-protein components (fat and lactose) can behave as plasticizers in the film formulation [25]. As referred to in the literature, glycerol, xylitol, sorbitol, sucrose, propylene glycol (PG), polyethylene glycol 200 (PEG 200), and polyethylene glycol 400 (PEG 400) are common plasticizers used in WP films.

The variation in molecular mass, chemical structures, and several hydroxyl groups account for the difference in films solubility, mechanical, and barrier properties $[3,13]$. The incorporation of glycerol in WP films improved the equilibrium moisture contents and solubility [34]. Higher glycerol levels improved the solubility and WVP of WP films, although mechanical resistance, apparent Young modulus, and glass transition temperature reduced [35,36]. Similar studies on sorbitol inclusion into WPI films improved moisture and oxygen barriers against glycerol plasticized films [20]. Perez et al. [37], stated that WPC films plasticized with trehalose had high insolubility in water compared with WPC/glycerol films, signifying more appropriateness for food applications. 


\subsubsection{Polysaccharides}

Polysaccharides are generally blended with proteins to enhance the mechanical and barrier properties of the films and coatings. The electrostatic interaction among proteins and polysaccharides (alginate, carboxymethylcellulose, and pectate) improves the cohesion among the protein polypeptide by cross-linking of proteins [38]. Several polysaccharides and their derivatives, which include starch, cellulose agar, alginate, carrageenan, chitosan, pectin, gellan, pullulan, and gums (arabic gum, guar gum, xanthan gum, etc.), are commonly incorporated into protein films [13].

Yoo and Krochta [39] found that WP films combined with hydroxypropyl methylcellulose (HPMC) were more robust than pure WP films. The OP in WP + HPMC films was also lower than pure WP films. Furthermore, WP + HPMC films revealed a substantial outcome on the flexibility, toughness, elongation, and water solubility [40]. Muñoz et al. [41] produced films blended with WPC and mucilage (ramified polysaccharide) of Salvia hispanica.

Films made with higher polysaccharide amounts and $\mathrm{pH} 10$ displayed superior mechanical and barrier properties, along with high resistance and flexibility. The water vapor barrier of those films were higher than in films made at $\mathrm{pH}$ 7. In a study by Basiak et al. [42] on starch incorporation into WPI films, variation in surface properties was observed corresponding to the WP/starch ratio and mainly allied to the polar component of surface tension. Films made with $20 \% \mathrm{WP}+80 \%$ starch displayed more hydrophobic surfaces than the others due to specific interactions.

\subsubsection{Lipids}

Although plasticized WP films are bland, flexible, and transparent with outstanding aroma, oxygen, and oil barrier properties, their hydrophilic nature makes them less effective moisture barriers. The inclusion of lipids in WP-based films can also provide a plasticizer effect and improve those properties [43,44]. Lipids commonly included in WP films comprise waxes (beeswax, carnauba wax, candelilla wax, etc.), oils (vegetable and mineral oil), acetylated monoglycerides, fatty acids, triglycerides (anhydrous milk fat fractions), and surfactants [13]. At temperatures beyond the melting point of lipids, lipids are homogenized into film solutions containing heat-denatured WP and plasticizers. The barrier property of resultant films firmly hinges on the polarity of film components and the dispersal of lipid material onto the film matrix [3].

Soazo et al. [22] stated that incorporating beeswax in WP films effectively improved the moisture barrier properties. Janjarasskul et al. [45] stated that incorporating candelilla wax into WPI films increased the hydrophobicity, thereby, improving the moisture barrier properties. The films were slightly sweet and sticky without a unique milk odor. Additionally, films without wax appeared glassy and transparent, while films made with wax were opaque [34]. Studies on the addition of almond and walnut oils in WPI films showed reduced water vapor permeability, surface hydrophilicity, and weakened mechanical resistance. Moreover, almond oil offered an improved plasticizing effect in WPI films over walnut oil [46]. All protein-plasticizer solutions, either alone or emulsified with a lipid, were degassed until no air bubble occurred to confirm accurate permeability values.

\subsection{Cross-Linking}

In efforts to enhance the properties of WP edible films, various methods of crosslinking were employed. In particular, the cross-linking desired in WP films may be achieved by irradiation. Ionizing irradiation, such as $\gamma$-irradiation, causes irreversible conformation modifications in proteins through amino acids oxidation, protein free radical formation, covalent bond breakage, and recombination and polymerization reactions [12]. Primarily, $\gamma$-irradiation produces hydroxyl radicals from water to interact with amino acid residues, of which aromatic amino acids are chosen over aliphatic amino acids [38]. In WP, $\gamma$-irradiation creates dityrosine bridges among protein chains resulting in insoluble and sterile films.

However, dityrosine bridges in WP films are inadequate in nature because of the fewer tyrosine residues in $\beta$-Lg. Cross-linking DW proteins by heat or $\gamma$-irradiation and 
entrapping into cellulose produced insoluble films holding good mechanical properties, reduced WVP, and more resistance to proteolytic enzymes. X-ray diffraction studies revealed cross-linking with $\gamma$-irradiation-altered conformation of DW proteins making them further ordered and stable [11].

Ultraviolet (UV) radiation may also be utilized in film formation via generating covalent cross-linking of WP. Under UV treatment, double bonds, and aromatic rings results in the free radical formation of amino acid residues that make new cross-links to produce a protein-film network. As higher radiation amounts bring improved interactions, UV-irradiated WP films display better strength; although the barrier properties are not considerably affected $[12,47]$.

Furthermore, the addition of a chemical cross-linking agent, like formaldehyde, could enhance the insolubility, mechanical properties, and glass transition temperature of film [35]. Treatment of WPI film-forming solutions with chemical cross-linking agents like glutaraldehyde, dialdehyde starch, and carbonyldiimidazole significantly improved the insolubility and tensile strength of films [47].

The main limitation of using chemical cross-linking agents is related to the toxicity of aldehyde residues inside the protein network and are mostly not acceptable for food applications. Conversely, enzymatic cross-linking methods through peroxidase and mainly transglutaminase (TGase) have gained much attention. TGase is mostly used for the crosslinking of WP films. TGase is a $\mathrm{Ca}^{2+}$-dependent enzyme that forms $\varepsilon$ - $(\gamma$-glutamyl) lysine cross-links into proteins by catalyzing the acyl transfer reaction. This reaction initiates covalent cross-linkages among WP, and between peptides and primary amines, to provide better mechanical stability that enhances the strength of protein-based films [12].

The incorporation of TGase into film solution improved the mechanical strength and oxygen barrier properties of the film, while lowering the WVP. Apparently, very similar flexible, transparent, and light yellowish films with smooth surfaces were formed by grafting spray-dried whey from bovine milk with chitosan in the absence and presence of TGase [12,48]. The TGase cross-linked films displayed poor solubility on a wide $\mathrm{pH}$ range, a low degree of swelling, and excellent biodegradability after protease treatments [11]. Marquez et al. [49] stated that the addition of TGase in WP/pectin edible coatings of doughnuts and French fries reduced moisture loss and improved the WVP due to a dense protein network.

\subsection{Active Ingredients}

\subsubsection{Antimicrobials}

Antimicrobial packaging is a type of active packaging to lengthen the shelf-life of food products and afford microbial safety for consumers. Antimicrobial agents are traditionally included in foods via matrix formulation; however, their activity can be hindered using several compounds in the matrix, thereby, reducing the efficiency. Under such conditions, incorporating antimicrobial compounds in films/coatings can be effective, as these compounds electively and steadily transfer from the packaging material into the food surface and disperse subsequently into the food, thereby, maintaining quite large concentrations on the food surface for more extended periods [26,50].

Antimicrobial films/coatings are, in fact, quite innovative in the global scope of active packaging, that delay, diminish, or further prevent the growth of pathogenic and deteriorating microorganisms on the food package. The microbial growth usually begins on the surface because of post-processing steps and handling. The selection of suitable coatings to preserve antimicrobial compounds on the surface can decrease the usage levels of antimicrobial compounds apart from excluding the necessity to compensate for the levels transported into the products [13].

Several factors, including the outcome of antimicrobial agents on the physical and mechanical properties of coatings, the range of antagonistic microorganisms, antimicrobial mechanism, migration into the food, and toxic concerns, along with their effect on the composition of food products, need to be counted while developing antimicrobial 
films/coatings. For instance, spraying of protective compounds, like organic acids, onto food surfaces rapidly move into the food interior, making the surface more prone for microbial contamination $[13,26,51]$.

The most common antimicrobial agents employed for edible coatings include bacteriocins (nisin), enzymes (lysozyme), inorganic gases (carbon dioxide), organic acids, polysaccharides (chitosan), fatty acids, fungicides (natamycin), plant extracts (essential oils), and spices (garlic) [13,50]. Data on concentrations used and their antimicrobial properties to restrict several target food-borne pathogens is extensively presented in the literature [51].

Evidence on the antimicrobial activity of bioactive agents included in WP films is scarce and has been evaluated mostly under in vitro by the film disc agar diffusion assay [52-55]. Recently, few studies have succeeded in incorporating antimicrobial agents, such as potassium sorbate and natamycin [56]; lactoferrin, lactoperoxidase, and lysozyme [56]; p-aminobenzoic, and sorbic acids [53]; citric, lactic, malic, and tartaric acids and nisin [57]; and essential oils from oregano, rosemary, and garlic [55], into WP films/coatings.

Plant extracts, mainly essential oils from oregano, cinnamon, rosemary, and garlic, etc. are commonly applied as antimicrobial agents in active film formulation. Oregano essential oil is the most studied essential oil in food applications for its antimicrobial and antioxidant properties. WP films containing $1.5 \%$ oregano oil exhibited higher antimicrobial activity with inhibition zones ranging from 0 to $1.7 \mathrm{~cm}$ [58]. Seydim and Sarikus [55] noticed WP film fused with oregano and garlic essential oils were more effective against Escherichia coli O157:H7, Listeria monocytogenes, Lactobacillus plantarum, Staphylococcus aureus, and Salmonella enteritidis, compared with rosemary oil.

Furthermore, fresh skinless chicken breast coated using WPI films with oregano essential oil displayed higher inhibition against Listeria innocua, Pseudomonas fragi, S. aureus, and S. enteritidis when compared to clove, coriander, laurel, mastic thyme, rosemary, sage, and tea tree oils [59]. WP films developed with cinnamon oil showed significant antibacterial and antifungal activities against Bacillus subtilis, Candida albicans, E. coli, Lactobacillus lactis, L. monocytogenes, Pseudomonas putida, and Streptococcus agalactiae [60].

Few compounds such as nisin (a natural bacteriocin) and lysozyme are effective food preservative agents in edible films and reliable for human consumption [16,61,62]. WPI films incorporated with nisin showed a decline of L. monocytogenes counts at $\mathrm{pH} 3$ and $6000 \mathrm{IU} / \mathrm{g}$ [52]. WPI films casted with mixtures of lysozyme and lactoperoxidase prolonged the storage of smoked salmon via inhibition or growth reduction of L. monocytogenes and aerobic microorganisms (yeasts and molds) $[54,62,63]$. Lysozyme hydrolyses linkages in peptidoglycan cell walls triggering cell lysis, and lactoperoxidase oxidize thiocyanate to hypothiocyanate, which is further oxidized to sulphydryl groups by microbial enzymes [27].

WPI coatings blended with mixtures of nisin, malic acid, grape seed extract, and ethylenediaminetetraacetic acid declined L. monocytogenes, Salmonella typhimurium, and E. coli O157:H7 in turkey frankfurter samples stored for 28 days at $4{ }^{\circ} \mathrm{C}$ [64]. Boyaci et al. [65] developed a $\mathrm{pH}$ triggering WP antimicrobial film comprised of oleic acid, beeswax, and lysozyme for preserving unwrapped packaged food at home. These films increased the released enzyme levels and displayed antimicrobial activity against Listeria innocua at below pH 5 on smoked salmon slices. WPI films, comprising $1.5 \%$ p-aminobenzoic acid and sorbic acid, produced inhibition against L. monocytogenes, E. coli O157:H7, and S. typhimurium, respectively [66].

In some cases, antimicrobial agents not only restricted the microbial growth but also altered the physical properties of active films. Increasing oregano oil concentration $(0.5-1.5 \%, \mathrm{v} / \mathrm{v})$ in WP films resulted in higher flexibility and WVP while decreasing the water solubility. Oregano oil at $1 \%$ improved the tensile strength and water resistance in films [58]. Likewise, incorporating p-aminobenzoic acid and sorbic acid improved the percent elongation while reducing the tensile strength. WVP remained unaffected at $0.5 \%$ and $0.75 \%$ of sorbic acid; whereas, p-aminobenzoic acid improved the WVP [66].

The antimicrobial assessment of active WP coatings in actual food applications is much lower. Very few studies are available on cheese, meat, or fish products $[3,54,62,66-68]$. In 
hot dogs (60\% beef $+40 \%$ pork), the inhibition of L. monocytogenes was more efficient through WPI castings with $p$-aminobenzoic acid than with sorbic acid [67]. On the other hand, observations for sliced Bologna and summer sausages against L. monocytogenes, E. coli, and S. typhimurium were contrary, which might be due to the natural $\mathrm{pH}$ of each product. These results implied that organic acids are more effective in their undissociated form (at pH 5.2) and can be appealing as antimicrobial agents for application in coated food products, such as cheeses or fermented meat with an acidic $\mathrm{pH}$ [66].

Zinoviadou et al. [68] evaluated the impact of antimicrobial films prepared with sodium lactate and 3-polylysine into sorbitol-plasticized WPI films against fresh beef stored at $5{ }^{\circ} \mathrm{C}$. The total counts and pseudomonads were significantly reduced in films made with $2 \%$ sodium lactate. WP films mixed with $1-2.5 \%$ thyme essential oil showed higher antimicrobial activity and doubled the shelf life of fresh beef meat stored for 12 days at $5{ }^{\circ} \mathrm{C}$ compared to cinnamon and/ cumin oils. Additionally, total viable bacterial counts were significantly reduced in all WP films added with $2.5 \%$ essential oils [69].

\subsubsection{Probiotics/Prebiotics}

In recent times, the inclusion of probiotics and prebiotics in food products through plasticized thin-layered hydrocolloids demonstrated the ability to improve and functionalize the health qualities in processed foods $[15,70]$. WP films combined with probiotics can also be utilized for their antimicrobial activity. The incorporation of Lactobacillus sakei NRRL B-1917 in WP films decreased $1.4 \log 10$ CFU g ${ }^{-1}$ of L. monocytogenes after $120 \mathrm{~h}$, while E. coli reduced $2.3 \log 10 \mathrm{CFU} \mathrm{g}^{-1}$ during $36 \mathrm{~h}$ at refrigerated storage [71]. Edible WPI-kefiran films acts as a new alternative in the delivery of probiotics, Lactobacillus paracasei, and Kluyveromyces marxianus to the gut. The films presented good mechanical and optical characteristics and protected the probiotics from stress during film formation and gastrointestinal passage simulation [72].

\section{Technological Properties of Edible Whey Protein Films/Coatings}

The feasible role of WP in food packaging relies strongly upon their inherent physicochemical characteristics; edible materials must meet the same standards required on usual food packaging materials. The above criteria include barrier (aroma, gas, light, and water vapor), optical (transparency), and mechanical properties that depend on the type of components, film structure, and composition [10]. Hence, the significance of precise methods in determining film performance is mandatory. These methods evolved from the conventional approaches applied for synthetic materials; however, modifications are done to meet whey film specifications, primarily because of their significant impact of relative humidity and temperature on the final film qualities [3,12].

\subsection{Barrier Properties}

Water vapor and gas permeabilities are generally considered barrier properties to define the strength of edible films / coatings to shield packaged foods against unfavorable environmental conditions and food components. Fluids (oil) and aroma permeabilities are the least important in various foods, and thus have acquired much less attention. High or low barrier properties are necessary for certain materials, depending on the food product. Permeation measurements make it possible to determine the barrier performance of packaging materials.

Permeation describes the rate at which gas (or vapor) is transferred through the packaging material, influenced by the variation in unit pressure among the two sides of the material at stated humidity and temperature conditions [73]. The permeation mechanism in a film mainly depends on sorption and/or adsorption of transmitted substances in/on the packaging material and contents, along with the diffusion across the interfaces between packaging and content, or packaging and atmosphere. Permeation may be expressed mathematically using Henry's law and Fick's law [12]. 
The barrier properties of WP films/coatings principally hinge on the coating material composition, density, and various layers used, such as the substrate. The low OP in WP films possibly offers their suitability for coatings/other film material used in oxygensensitive products $[36,74]$. However, the intrinsic protein hydrophilicity results in low moisture barriers that limit their use. In addition, stimulated interaction with water creates swelling and apparent thickness effects that deviate from Henry's law and Fick's law [12].

\subsubsection{Water Vapor Permeability}

Water activity (aw) is one of the essential elements to affect the sensory quality and shelf life of food, which can be determined by the moisture levels and interactions of water molecules with other ingredient molecules. Many chemicals and enzymatic degradation events (lipid oxidation, Millard, and enzymatic browning), along with microbial activity in storage, are controlled by aw; moreover, the textural properties in some foods are greatly relied on aw. Henceforth, WVP acts as an essential trait of WP edible films/coatings since it controls the water vapor transport and water balance among the food system and its environment $[10,12]$.

The "Cup method" is the most common way to measure WVP; this gravimetric technique includes sealing a WP film in a plastic cup partly filled with either distilled water or desiccant, thereby, giving an air space below the film. Cup weights were determined at specific intervals, and linear regression analysis of the increase in weight versus time was achieved. The slope of the line in gram per hour provided the water vapor transmission rate (WVTR). WVP is estimated based on the below calculation:

$$
\mathrm{WVP}=\frac{\text { WVTR } \times \text { thickness }}{\text { WVPP }}
$$

where WVTR is in $\mathrm{gh}^{-1} \times \mathrm{m}^{-2}$, the thickness is in millimeters, the partial pressure is in kilopascals, and WVPP is the water vapor partial pressure [3,26].

The WVP concept helps understand the solute-polymer interactions and mass transfer mechanisms in edible films [73]. The hydrophilic nature of WP controls the ability to produce films with suitable moisture barrier properties indicating the loss of weight (because of moisture) in food product only occurs when synthetic films are employed. WP films most effectively limit the water vapor condensation in fruit and vegetable packaging, thereby, restricting microbial spoilage. For same reasons, the $\mathrm{RH}$ and plasticizer type significantly influence the moisture permeability properties of protein films $[3,10,20]$.

\subsubsection{Gas Permeability}

Oxygen permeability (OP) is the next most widely investigated carrier property in edible films; as oxygen involves several food decomposition reactions, including rancidity of fat and oil, growth of microorganisms, enzymatic browning, and loss of vitamins. As a result, several packaging methods require oxygen-protective packaging [10]. However, the packaging of fresh fruits and vegetables demands mild barrier films/coatings as OP and carbon dioxide permeability (CP) is necessary for respiration. OP can be evaluated by the standard method (D3985/D618) of American Society of Testing and Materials (ASTM), while for $\mathrm{CP}$, the method used for WVP has been adopted with some modifications $[3,26]$.

Even if the same plasticizer and similar RH conditions were employed, the OP of WP films is poorer than conventional synthetic polymers [20]. This may be due to the latter's polar nature and linear structure, which results in a higher cohesive energy density and lower free volume. The moderate low OP in WP films/coatings improves the chemical quality by avoiding oxidative damage of lipid ingredients and deterioration by aerobic microflora, as seen on colored produce, confectionery, fried products, fresh fruits and vegetables, and nuts [3,10].

Compared to films made from other protein sources, such as collagen, wheat gluten, and soy protein, WP films / coatings seem to have a higher OP. These properties can provide food a smooth, shiny surface further shielding them against aroma loss, aging, dehydration 
and moisture migration. Yet, modifying the polymer structure by blending with plasticizers can influence the polymer-free volume, thus, further reducing the OP [10]. Several factors, such as the type of plasticizer (glycerol/sorbitol), WPI/plasticizer ratio, and RH, can affect the OP values in WPI films.

The gas permeability of edible films can be influenced by the $\mathrm{RH}$, temperature, thickness, and WVP. Maintaining the RH is crucial for maximizing the efficiency of edible films as gas barriers, as a higher RH can substantially increase OP [1]. Thicker coatings can adversely affect food by decreasing inner oxygen partial pressure while increasing $\mathrm{CO}_{2}$ levels, resulting in anaerobic fermentation. Moreover, thicker coatings limit the exchange of respiratory gas and develop off-flavors in the product due to elevated ethanol concentration $[3,12]$.

\subsubsection{Flavor/Aroma Permeability}

In addition to barrier properties revealed by several molecules in edible films/coatings, much attention is paid to the molecules associated with flavor and aroma, (i) to reduce adsorption and loss of such molecules, which could deteriorate the sensory values of food; and (ii) for precise release of molecules from films in a controlled manner [10]. Nevertheless, protein films with aroma barrier properties have gained significantly less attention, apart from the fact that WPI is an exceptional $\delta$-limonene barrier. The $\delta$-limonene transport in WPI films blended with $25 \%$ glycerol was comparable to ethylene vinyl alcohol copolymer (EVOH) films [20]. Moreover, the permeability of WPI films to $\delta$-limonene was considerably influenced by the temperature and RH but not on permeant concentrations [3].

\subsection{Mechanical Properties}

Packaging materials must hold ample mechanical strength and extensibility for sustaining the integrity and withstand external forces during processing, handling, and storage. The mechanical properties of WP-based films and coatings are determined by the formulation and processing methods involved in film-formation. Moreover, film thickness and testing conditions also influence the mechanical properties; hence it is mandatory to maintain strict control over working conditions while testing [12,73].

Like conventional packaging materials, puncture and tensile tests are mostly applied to evaluate the mechanical properties of WP films, although tensile tests are more commonly used in research works. The characteristic properties determined by tensile tests are tensile strength (TS), elongation (E), and Young modulus (Ym): TS is expressed as the maximum stress/load that a material can sustain during the tensile test; $\mathrm{E}$ is the percentage of original length of the material before it breaks; and Ym measures the tensile stiffness of a material and calculated as the initial linear part of the stress/strain curve [3].

Two factors highly influence the mechanical properties of WP-based films. First, the three-dimensional protein network developed in film processing. An intensive cross-linked network leads to more robust and firmer materials, which results in higher modulus and strength. Moreover, the material is less flexible as it is commonly associated with lower elongations [12]. Cross-linking agents, like formaldehyde or glutaraldehyde, can significantly improve the mechanical strength in glycerol-plasticized WPI films. Nevertheless, these chemicals lack food safety approval and are often unsuitable in food packaging [11,47].

The second consideration is the presence of plasticizers, including water. Accordingly, factors like RH and the storage conditions of the film should be under control. When the water content in films/coatings is increased, the RH substantially alters the mechanical strength by reducing modulus and strength while increasing the elongation values. A similar effect can be observed with various plasticizers. Films develop into less rigidity at increasing contents, causing lower tensile strength and higher flexibility with extended elongation values [3,11].

The incorporation of plasticizers allows less intermolecular interactions among the protein chains. Mechanical performance is influenced not only by the ratio but also by the plasticizer type used. Glycerol plasticized with $\beta$-Lg films showed an increase in 
elongation and decrease in tensile strength, followed by polyethylene glycol (200), sucrose, and polyethylene glycol (400) [75]. Compared to WPI films plasticized with glycerol, films plasticized with sorbitol and xylitol have a much lower tensile strength [76].

Schmid et al. [77] stated hydrolyzed whey protein isolate (HWPI) could serve as an internal plasticizer. Increasing levels of HWPI in WP films with a fixed glycerol concentration significantly improved film flexibility despite maintaining their barrier properties. Schmid [78] took these facts into account when creating formulations to improve barrier performance with maintaining film flexibility. In WPI-based cast films, partial replacement of glycerol for HWPI as an internal plasticizer resulted in better oxygen and water vapor barrier properties while maintaining mechanical properties. In this method, the film flexibility was retained even at reduced external plasticizer levels $[77,78]$.

\subsection{Surface Properties}

Surface properties, such as cohesion and adhesion are critical in films/coatings as well as multilayer systems. The cohesion of a polymer is an outcome of a strong interaction that forms several molecular bonds between the adjacent polymers, thereby, preventing their separation. This ability mainly depends on the structure of polymer, which includes the geometry, general molecular strength, molecular mass distribution, and type and position of lateral functional groups [12].

The surface morphology of WP-coated apple skin was resolved using scanning electron microscopy, confocal Raman micro spectrometry, surface-enhanced Raman scattering, and Fourier transform Raman spectrometry [3,79]. For achieving the full advantage of edible films, the food surface needs to be entirely covered by the coating material. As with most hydrophilic edible coatings, the adhesion of WP films is poor in nature due to discrete chemical composition between the two contact surfaces.

In addition, if the film-forming materials include mixed components that are not compatible with WP, the cohesion of resultant films reduces and weakens the film strength. Hence, before testing new additives, the compatibility of all ingredients must be well known for achieving strong cohesion. Since plasticizers are proven to decrease the cohesion of film-forming polymers, surface adhesion in WP coatings can be achieved with a surfactant (Tween or lecithin) that reduces surface tension and simultaneously enhance wettability [1]. In addition, microbial TGase improved the hydrophobicity of WP films by exposing the hydrophobic groups through moderate cross-linking [48,80].

\subsection{Optical Properties}

As consumers are fascinated with the external view of the food product during purchase and consumption, the optical properties (color, transparency, and ultraviolet- or light-barrier properties) of material are essential traits in films, particularly designated for use in food packaging. Polymers from natural resources like WP generally include organic colored molecules. Human color vision is not a physical number and cannot be measured using conventional mathematical methods [12]. However, colors are quantified using three distinct color values in a three-dimensional color space via methodologies including the CIE L*a*b* system, Hunter Lab, CIE LCH, or CIE XYZ [3].

A colorimeter is used for the measurements, and a single numerical value states the color difference, $\Delta \mathrm{E}^{*}$, that specifies the magnitude of the color difference but not the quality of such a difference. Colorimeters with such systems can determine color differences $\Delta \mathrm{E}^{*}$ between two or more layers. The transparency of the film is mainly determined through ASTM D1746 and evaluated using the calculation proposed by Han and Floros [81]. A calibrated spectrophotometer with selected wavelengths $(200-600 \mathrm{~nm})$ can measure the ultraviolet and visible light barrier properties of a film. WPI-based edible films exhibit better transparency than few synthetic films. Generally, apart for colorless compounds, addition of plasticizer increases $E^{*}$, (e.g., glycerol) due to a dilution effect. However, the final properties also depend on the film thickness [3,12]. 


\section{Potential Application of WP-Based Edible Films/Coatings in Foods}

The potential interest on the application of WP-based edible films and coatings in the food packaging industries is considerably gaining much attention because of their high nutritional value and potential delivery of active ingredients (antimicrobials, antioxidants, and anti-browning agents). Table 1 summarizes an updated overview on the successful application of WP-based films and coatings on several foods.

Table 1. An overview on the application of WP-based edible films and coatings on food packaging.

\begin{tabular}{|c|c|c|c|}
\hline $\begin{array}{l}\text { Whey Protein-Based Film/Coating } \\
\text { Composition }\end{array}$ & Function & Food Products & References \\
\hline \multicolumn{4}{|c|}{ Dairy products } \\
\hline WPC-pullulan + beeswax & Improve water vapor permeability & Milk & [82] \\
\hline WPC & Improve oxygen permeability & Cheddar cheese & [83] \\
\hline $\begin{array}{c}\text { WPI + natamycin/chitooligosac- } \\
\text { charides/lactic } \\
\text { acid }\end{array}$ & $\begin{array}{l}\text { Reduce moisture loss } \\
\text { Inhibit pathogens }\end{array}$ & Cheese & [51] \\
\hline WP-chitosan & $\begin{array}{c}\text { Reduced microbial growth, delay acidity } \\
\text { development, extend shelf life }\end{array}$ & Ricotta cheese & [84] \\
\hline \multicolumn{4}{|c|}{ Fruits and vegetables } \\
\hline WPI & Reduce ripening rate & Banana & [85] \\
\hline WPI & Reduce respiration & Apples & {$[86]$} \\
\hline WPI-bee wax & Reduce enzymatic browning & Fresh-cut apple & [87] \\
\hline WPI + glycerol/trehalose & $\begin{array}{l}\text { Reduce browning, reduce weight loss, } \\
\text { maintenance of phenolic compounds }\end{array}$ & Apples & [88] \\
\hline WP-pectin + transglutaminase & $\begin{array}{l}\text { Reduce weight loss, inhibit spoilage } \\
\text { microorganisms, increase antioxidant } \\
\text { activities, maintain the firmness and } \\
\text { texture of the products }\end{array}$ & Apples, carrots and potatoes & [89] \\
\hline WPI & Reduce weight loss & Asparagus & [90] \\
\hline WPI & Reduce rehydration & Strawberry & [91] \\
\hline WPI & $\begin{array}{l}\text { Reduce color changes and reduce loss } \\
\text { of hardiness }\end{array}$ & Fresh-cut pears & [92] \\
\hline $\mathrm{WP}+$ rice bran oil & $\begin{array}{l}\text { Reduce weight loss, } \\
\text { Increased acidity }\end{array}$ & Kiwi & [93] \\
\hline $\mathrm{WPC}+$ rosemary & Reduce weight loss, oxygen barrier & Fresh spinach & {$[94]$} \\
\hline \multicolumn{4}{|c|}{ Egg and meat } \\
\hline $\begin{array}{l}\text { WPI + sodium montmorillonite } \\
\text { nanoparticles }+ \text { sodium } \\
\text { metabisulfite }\end{array}$ & $\begin{array}{l}\text { Reduce weight loss and increase } \\
\text { foam stability }\end{array}$ & Eggs & [95] \\
\hline $\begin{array}{c}\text { WPI + sorbitol + oregano essential } \\
\text { oil }\end{array}$ & $\begin{array}{l}\text { Reduce viable bacterial counts } \\
\text { and pseduomonads }\end{array}$ & Beef cut & [96] \\
\hline $\begin{array}{c}\text { WPI + sodium } \\
\text { lactate + 3-polylysine }\end{array}$ & $\begin{array}{l}\text { Reduce viable bacterial counts and } \\
\text { pseduomonads }\end{array}$ & Fresh beef cut & [68] \\
\hline $\begin{array}{l}\mathrm{WP}+\text { cinnamon/ cumin/thyme } \\
\text { essential oils }(1-2.5 \%)\end{array}$ & Reduce viable bacterial counts & Fresh beef & [69] \\
\hline WPI + tea extract & Reduce protein oxidation & $\begin{array}{l}\text { Beef steak and } \\
\text { catfish fillet }\end{array}$ & [97] \\
\hline
\end{tabular}


Table 1. Cont.

\begin{tabular}{|c|c|c|c|}
\hline $\begin{array}{l}\text { Whey Protein-Based Film/Coating } \\
\text { Composition }\end{array}$ & Function & Food Products & References \\
\hline WPC+ sea weed extract & Inhibit lipid oxidation & Fresh poultry meat & [98] \\
\hline WPI & Reduce mechanical loss & Freeze dried chicken & [99] \\
\hline WP-alginate + lactoperoxidase & $\begin{array}{c}\text { Increase antibacterial activity against } \\
\text { Enterobacteriaceae spp. }\end{array}$ & Chicken thigh meat & [100] \\
\hline $\begin{array}{c}\text { WP- chitosan }+ \\
\text { cranberry or quince juice }\end{array}$ & $\begin{array}{l}\text { Inhibit S. typhimurium, Escherichia coli, } \\
\text { and Campylobacter jejuni }\end{array}$ & Fresh cut turkey & [101] \\
\hline $\mathrm{WP}+$ Origanum virens essential oils & $\begin{array}{l}\text { Increase shelf life up to } 15 \text { days, reduce } \\
\text { discoloration and lipid oxidation }\end{array}$ & Sausages & [102] \\
\hline \multicolumn{4}{|c|}{ Seafood } \\
\hline WPI-Acetylated Monoglyceride & $\begin{array}{l}\text { Reduce rancidity and } \\
\text { Reduce weight loss }\end{array}$ & Frozen salmon & [103] \\
\hline $\begin{array}{l}\text { WP+ transglutaminase or } \\
\text { ultrasound treatment }\end{array}$ & Inhibit lipid oxidation & Frozen Atlantic salmon & [104] \\
\hline $\begin{array}{l}\text { Whey protein-sodium alginate } \\
\qquad(0.5 \%) .\end{array}$ & $\begin{array}{l}\text { Reduce counts of bacterial and } \\
\text { Staphylococcus spp. }\end{array}$ & Kilka & [105] \\
\hline $\mathrm{WP}+$ lactoperoxidase & $\begin{array}{c}\text { Reduction of Shewanella } \\
\text { putrefaciens and Pseudomonas fluorescens }\end{array}$ & Rainbow trout & [106] \\
\hline WPI + thyme essential oil ( $3-7 \%)$ & Enhance quality & Trout & [107] \\
\hline WPC + glycerol & Increased shelf life & Rainbow trout & [108] \\
\hline $\begin{array}{l}\text { WPI + ginger and chamomile } \\
\text { essential oils }\end{array}$ & Reduce bacterial growth & Rainbow trout fillets & [109] \\
\hline $\begin{array}{l}\text { WPC + cinnamon + rosemary } \\
\text { essential oils }(1-5 \%)\end{array}$ & Inhibit lipid oxidation & Salami & [110] \\
\hline $\begin{array}{l}\text { WPI-cassava starch }+ \text { rambutan } \\
\text { peel extracts }+ \text { cinnamon oil }\end{array}$ & Reduce microbial growth & Salami & [111] \\
\hline \multicolumn{4}{|c|}{ Nuts } \\
\hline WPI & Reduce rancidity & Dry roasted peanut & [112] \\
\hline WPI-pectin + transglutaminase & Moisture barrier & Roasted peanut & [113] \\
\hline WPI & Reduce rancidity & $\begin{array}{l}\text { Dry roasted peanuts and } \\
\text { walnuts }\end{array}$ & [114] \\
\hline $\begin{array}{l}\text { WPC + glycerol/carboxymethyl } \\
\text { cellulose/rosemary extract }\end{array}$ & Desirable color with oxidative stability & $\begin{array}{l}\text { Sunflower seed } \\
\text { kernels }\end{array}$ & [115] \\
\hline WPC + glycerol & $\begin{array}{l}\text { Reduce oxidiation, } \\
\text { extend shelf life }\end{array}$ & $\begin{array}{l}\text { Dried pistachio } \\
\text { kernels }\end{array}$ & [116] \\
\hline \multicolumn{4}{|c|}{ Miscellaneous } \\
\hline WPI & Aroma barrier & Flavor (d-limonene) & {$[117]$} \\
\hline WPI & Reduce fat uptake during frying & Deep fried cereal mix & [118] \\
\hline $\begin{array}{l}\text { WP + sodium alginate }+ \\
\text { Lactobacillus rhamnosus GG }\end{array}$ & $\begin{array}{c}\text { Retention of sensory properties, } \\
\text { Increase cell viability of L. rhamnosus GG }\end{array}$ & Bread & [119] \\
\hline
\end{tabular}

WP-Whey protein; WPI—Whey protein isolate; WPC—Whey protein concentrate.

\subsection{Dairy Products}

Cheese is a ready-to-consume dairy food that got easily contaminated by detrimental microorganisms on the surface resulting in spoilage and off-flavors [120]. Furthermore, higher levels of moisture loss in few cheese varieties could lead to several undesirable organoleptic alterations [13]. Wagh et al., [83] prepared WP films to protect Cheddar cheese 
and found that characteristics and sensory properties of the products remain unaffected by coatings. The purpose of an edible WP-based coating infused with antimicrobial substances is an effective approach to prevent the growth of detrimental microorganisms and increase the shelf life of product [26,51].

WPI films impregnated with nisin (50 IU / mL), malic acid (3\%), sorbitol $(1.5 \%)$, and natamycin $(0.002 \mathrm{~g} / \mathrm{mL})$ displayed inhibitory activity on cheese surfaces against L. monocytogenes, Pseudomonas aeruginosa, Penicillium commune, P. chrysogenum, and Yarrowia lipolytica [121]. Ricotta cheese coated with chitosan/WP edible film and stored at $4{ }^{\circ} \mathrm{C}$ for 30 days showed a significant reduction in mesophilic and psychrotrophic counts compared to control [84]. Cheese coating with edible antimicrobial substances acts as an appropriate alternative for commercial coatings concerning moisture and weight loss barrier properties in cheese.

The storage of cheeses coated with a WP film blended with a mix of antimicrobial substances, such as natamycin + chitooligosaccharides (COS), natamycin + lactic acid, and natamycin + lactic acid + COS, inhibited the growth of contaminant or pathogenic microorganisms, while permitting lactic acid bacteria to grow normally during storage. In addition, reduction in water loss ( $10 \%$, by weight), hardness, and discoloration were also observed [51]. Henriques et al. [122] reported that edible WPC coatings prepared by heat denaturation or UV irradiation, and fused with antimicrobials (lactic acid and natamycin) seem to be a potential alternative for commercial coatings in ripened cheese. Lor cheese wrapped with WPI film incorporated with mint essential oil reduced the moisture loss to $4 \%$ lower than in control [123].

\subsection{Egg and Meat}

Eggs can quickly lose their quality in storage, due to changes of $\mathrm{pH}$, albumen, yolk, and weight loss. Such changes are generally influenced by the tiny pores on eggshells, which cause mass transfer of moisture and carbon dioxide [26]. WP film had effectively increased the shelf life of fresh egg quality during storage at room temperature. Storage of WP-coated eggs at room temperature for about four weeks recorded a weight loss of $2.38-2.46 \%$ compared to $5.66 \%$ in control (uncoated eggs). Coated eggs also had higher albumen quality and lower $\mathrm{pH}$ than control. The yolk index [102] values in coated eggs were $0.26-0.9$ indicating good quality even after four weeks [124].

The foremost challenges in applying edible films for meat products are to minimize the usage of chemical additives and reduce meat deterioration. Spoilage of meat quality can occur through lipid oxidation, microbial growth and myoglobin oxidation. WP films successfully demonstrated the decline in lipid oxidation and inhibition of the growth of spoilage and pathogenic microorganisms in meat products [14,101]. Catarino et al. [125] stated that adding Origanum virens essential oil to WPC film in two traditional Portugal sausages, painhos and alheiras suppressed the entire microbial load and prolonged the shelf life for approximately 20 and 15 days, respectively.

WP packaging mixed with natural antioxidant extracts reduced the moisture loss and showed lower thiobarbituric acid-reactive substances and peroxide values (PV) in sausage and cooked meatballs stored for 8 weeks at $4{ }^{\circ} \mathrm{C}$ [126]. Likewise, WPI based films blended with antioxidant extracts from laurel or sage, prevent oxidation in cooked meatballs, leading to lower para-anisidine and thiobarbituric acid values during frozen storage at $-18{ }^{\circ} \mathrm{C}$ for 60 days [127].

With a view on antimicrobial activity, Fernandez-Pan et al. [59] evaluated the effects of different essential oils from oregano, clove, coriander, laurel, mastic thyme, rosemary, sage, and tea tree on WPI films used for coating fresh skinless chicken breast. The results indicate that all films containing essential oils inhibited Listeria innocua, Pseudomonas fragi, S. aureus, and S. enteritidis, while films with oregano oil displayed the highest inhibition. WP edible films prepared with $2.5 \%$ thyme, cinnamon and cumin essential oils significantly reduced the total viable bacterial counts of fresh beef meat stored for 12 days at $5{ }^{\circ} \mathrm{C}$ [69]. Incorporating WP films with $6000 \mathrm{IU} \mathrm{g}^{-1}$ nisin, $1 \%$ malic acid and $0.5 \%$ grape seed extract 
declined L. monocytogenes counts from 5.5 to $2.3 \log \mathrm{g}^{-1}$ after 28 days at $4{ }^{\circ} \mathrm{C}$. WP films combined with nisin, organic acids, and natural extracts also exhibited promising antibacterial activity against E. coli O157:H7 and S. typhimurium [64].

\subsection{Seafoods}

Raw fish is a perishable food, because of its inherent aspects, including high water holding capacity, neutral $\mathrm{pH}$, tissular enzymes, low connective tissue content, and natural microbial contamination [128]. Freezing is a reliable way to preserve fish. Still, few undesirable changes, such as the denaturation of protein, loss of weight, and lipid oxidation, can occur. Phosphates are utilized in seafood to improve the water-holding capacity, while butylated hydroxyanisole (BHA) and butylated hydroxytoluene (BHT) is employed to inhibit lipid oxidation, thereby, increasing the shelf life of sea foods. Due to the rising demand of consumers for safer foods, coatings using biodegradable proteins, like WP, can be used for coating fish fillets to overcome any inherent changes in quality throughout the frozen storage [26].

Salmon includes a great deal of fat, mostly unsaturated fatty acids that are easily oxidized. A WP coating on frozen king salmon lowered the levels of moisture loss by $42-65 \%$ within the first 3 weeks of storage. It delayed lipid oxidation and reduced the peak PVs [103]. Studies on coatings prepared with $13 \%$ WP reduced the lipid oxidation during frozen storage of gutted Kilka [129].

In a comparison study of applying WPC coating before and after freezing Atlantic salmon, coatings applied after freezing improved the thaw yield, reduced drip loss, and altered the color constraints in frozen and thawed fillets. The sensory qualities of salmon fillets remain unaffected by coating [128]. The same group later demonstrated that ultrasound-treated WP coatings with or without addition of microbial TGase delayed lipid oxidation equally effective in frozen Atlantic salmon than heat treated coatings containing TGase [130].

\subsection{Fruits and Vegetables}

In fresh-cut fruits and vegetables, protein-based edible coatings can act as moisture or gas barriers, which may reduce moisture loss and/or reduce oxygen intake from the environment and later reduce the respiration rate $[9,10]$. Freshly sliced apples often change color because of enzymatic reactions between phenolic compounds with released endogenous polyphenol oxidase and the diffusion of atmospheric oxygen into the tissue. Edible WP coatings in apple and potato slices act as oxygen barriers and delay browning reactions [26]. WP appears to possess superior antioxidant capacity than calcium caseinate [131].

WP coating on apple pieces coated with emulsion film containing WPI or WPC and beeswax or carnauba wax displayed anti-browning effect with greater $\mathrm{L}^{*}$-, and lower $\mathrm{b}^{*}$-, $\mathrm{a}^{*}$ values [132]. WPC and bees wax based coatings with $1 \%$ ascorbic acid or $0.5 \%$ cysteine are shown to be the most effective means of preventing browning in apples [87]. The efficiency of WPI coatings can be influenced by the RH on the atmosphere. Under lower RH, levels of internal oxygen reduced, whereas carbon dioxide increased. Anaerobic respiration occurred in coated fruits under lower $\mathrm{RH}$ (about $70 \%$ to $80 \%$ ), due to the reduced oxygen levels (about $0.025 \mathrm{~atm}$ ) [86].

The antioxidative capacity in the film composition is considerably enhanced by including carboxymethyl cellulose (CMC). This mixture prevented up to $75 \%$ of the production of color compounds formed by the interaction of the oxidative species with $\mathrm{N}, \mathrm{N}$-diethylp-phenylenediamine [131]. WP coatings have also been utilized on plum, freeze-dried Chinese chestnut, and strawberry pieces, in addition to their frequent usage on apples. Plums coated with WP significantly reduced the weight loss in storage compared to uncoated plums [44].

Both freshly roasted and freeze-dried Chinese chestnut coated with WP-pullulan film revealed a delay of outer color changes in storage [133]. WPI coatings on freeze-dried strawberry pieces in milk showed substantially reduction of rehydration ratio, resolving the 
problems of "rapid rehydration velocity" and "loss of freeze-dried strawberry texture" [91]. Coatings of WP and rice bran oil on kiwi fruit stored for 28 days resulted in minimal weight loss and increased acidity, while preserving their total soluble solid materials, and maintaining their firmness, color, and sensory attributes [93].

Soazo et al. [134] examined the effect of prefreezing applications of WPC edible coatings on maintaining the quality characteristics of strawberries and found that WP coatings with $20 \%$ beeswax reduced weight loss in strawberries after thawing. Edible coatings prepared with WP/pectin in the presence of TGase effectively avoid spoilage in fresh-cut apples, carrots, and potatoes until 10 days by reducing the moisture loss, inhibiting microbial growth while their antioxidant properties, hardiness, and chewiness remained unaffected [89].

\subsection{Nuts}

Peanuts are rich in oil and unsaturated fatty acid contents that contribute high vulnerability to oxidative rancidity when coupled under high heat treatment in the roasting process. Autoxidation is the primary source of oxidative rancidity in roasted peanuts. Lipid oxidation is the most common cause of peanuts degradation, depending on the oxygen levels in storage [26]. The rate of lipid oxidation can be reduced through the usage of packaging systems or coating. The defense mechanism provided by the WP coatings depends on their ability to act as an oxygen barrier [10,135].

Native and heat-denatured WPI coating in the presence or absence of vitamin, delayed oxidation and prolonged the shelf life of peanut until 31 weeks at 40,50 , and $60{ }^{\circ} \mathrm{C}$ [112]. WPI coatings also prevent oxidative degradation in dry-roasted peanuts. During storage, WP coating decreased hexanal production by the oxidation of unsalted roasted peanut lipids, as measure by solid-phase micro-extraction and GC-MS. It is worth noting that coatings having a higher thickness and lower RH were more effective [135].

A WPI film or coating formulated with ascorbic acid (AA-WPI) prevented lipid oxidation significantly in peanuts stored at 23,35 , and $50{ }^{\circ} \mathrm{C}$. At all the said temperatures, the AA-WPI coated peanuts were much redder than in control (non-coated). WP coating incorporated with or without antioxidants, delayed oxidative rancidity in dry roasted peanuts. Even though WPI coatings have low OP and good continuity, the oxidative rancidity in walnuts was not significantly delayed [114]. That might be due to the inadequate protection offered by the WPI coatings leading to the shrinkage of WP coating during drying, which results in the release of some oil outside of the walnut tissue.

\section{Regulatory Aspects Relating to WP Edible Films/Coatings}

As packages serve as an integral part of food products, they must adhere to all foodrelated standards; in addition, they can be substantially influenced by and the first to be visible for consumer approval. The suppliers of edible films/coatings must obtain a "no-objection" notice from the concerned experts about the utilization of their film/coating products, as food ingredients, including careful consideration of accurate labeling with nutritional and allergen information $[3,7,33]$.

WP edible films/coatings can be applied as direct coatings, coatings on substrates, and stand-alone films, which could be categorized as food contact materials, food additives, or even food products, leading to diverse regulation aspects [9]. Accordingly, different legislation must be applied for each category. To be employed as an edible coating, the ingredients in the coating formulation must be generally food grade and standardized as additives under legislation (Regulation (EC) No. 1333/2008) [136].

As per regulation (EC) 1935/2004, protein-based films / coatings connected to foodcontact materials required to be produced as per good manufacturing practices that conveys the levels of ingredients in foods should not pose threat to human health, make unbearable changes in food composition changes or reduction in organoleptic traits [9]. In EC 10/2011, the EU specifies the limits of the plastic packaging materials and additives permitted for food contact and subsequent migration [12]. However, many ingredients 
employed for protein-based films / coatings are not in the list $[9,136]$. In conclusion, the corresponding regulatory aspects are based on formulations and application that requires individual evaluation.

\section{Conclusions and Future Perspectives}

The consumer's demand for products with health benefits and several natural ingredients has been significant for the growth of the functional food category. Edible films/coatings are an excellent way to diversify the market on functional foods and a substitute for the prevailing packaging and products. Incorporating WP and active ingredients into edible films / coatings is a budding technique and can be applied in various food products.

Numerous combinations could be used on an industrial scale depending on the purpose, product, nature of the film, type of active ingredient, and various inclusions. In this review, we described several traits of edible WP films/coatings as novel packaging materials. These are many promising ways to improve food quality, extend the shelf life, ensure safety, maintain functionality, and reduce environmental impacts. In addition, these films and coatings can be utilized as separate pouches of homogeneous substances and carriers of the active ingredient. The formulation of a biopolymer coating using WP-based plastic films can substitute for existing synthetic oxygen-barrier layers, such as EVOH in food packaging.

Meanwhile, whey is not in a direct food competition, as it is a by-product of cheese manufacturing. WP-based films / coatings outperform synthetic plastics in terms of intrinsic edibility and biodegradability. WP films/coatings explained in this review unveiled exceptional optical and barrier properties that surpass existing biopolymers. In this aspect, WP coatings have been proven as efficient gas barriers capable of acting as vehicles for several compounds that include antioxidants, antimicrobials, or different nutrients, although their mechanical properties need to be improved. Thus, chemical, physical, or enzymatic protein cross-linking [11] and other options, like blending and nanotechnology, are possible ways to improve the tensile strength and elongation at break characteristics of WP films.

In our view, the greatest potential for the commercial success of WP films/coatings includes delivery vehicles of functional and bioactive compounds in cheese, fruit, and vegetables, thereby, extending their shelf life and improving their safety, nutrition, and sensory qualities. WP-based multilayer laminates have been confidently authenticated for the storage of various food products. This innovative WP-coating can be detached to allow multilayer films to become reusable.

WP-based packaging ideas could play a beneficial role in sustainability due to their possibility of recycling materials rather than incineration, as done in synthetic laminates, due to the usage of natural by-products from the food industry as raw materials. However, cost-effectiveness will always be a driving force in current and future WP processing developments against industrial setbacks. The industrial application of this new technology still depends on further scientific research aimed to identify the mechanism of film-formation to improve the performance of both the product and process. Further, research attempts on consumer studies and long-term toxicity assessment require investigation before gaining considerable market share.

Author Contributions: Conceptualization: S.K. and J.-S.H.; investigation: writing-original draft preparation: S.K.; Data collection: S.K., J.Y. (Jayeon Yoo), J.Y. (Jeonghee Yun); H.-B.K.; Data curation: S.K., J.Y. (Jayeon Yoo), J.Y. (Jeonghee Yun); H.-B.K.; writing-review and editing-S.K. and J.-S.H.; supervision: J.-S.H., K.-H.S. and H.-W.K.; project administration: J.-S.H. and K.-H.S. All authors have read and agreed to the published version of the manuscript.

Funding: This work was supported by (2021) the RDA Fellowship program of the National Institute of Animal Science, Rural Development Administration, Republic of Korea (Project No: PJ01418702), and "Cooperative Research Program for Agriculture Science and Technology Development" Rural Development Administration, Republic of Korea.

Institutional Review Board Statement: Not applicable. 
Informed Consent Statement: Not applicable.

Data Availability Statement: Data sharing is not applicable to this article.

Conflicts of Interest: The authors declare no conflict of interest.

\section{References}

1. Karaca, O.B.; Oluk, C.A.; Taşpinar, T.; Güven, M. New concept in packaging: Milk protein edible films. In Health and Safety Aspects of Food Processing Technologies; Springer International Publishing: Cham, Switzerland, 2019; pp. 537-565.

2. Guimarães, A.; Abrunhosa, L.; Pastrana, L.M.; Cerqueira, M.A. Edible films and coatings as carriers of living microorganisms: A new strategy towards biopreservation and healthier foods. Compr. Rev. Food Sci. Food Saf. 2018, 17, 594-614. [CrossRef] [PubMed]

3. Ramos, Ó.L.; Fernandes, J.C.; Silva, S.I.; Pintado, M.E.; Malcata, F.X. Edible films and coatings from whey proteins: A review on formulation, and on mechanical and bioactive properties. Crit. Rev. Food Sci. Nutr. 2012, 52, 533-552. [CrossRef] [PubMed]

4. De Castro, R.J.S.; Domingues, M.A.F.; Ohara, A.; Okuro, P.K.; dos Santos, J.G.; Brexó, R.P.; Sato, H.H. Whey protein as a key component in food systems: Physicochemical properties, production technologies and applications. Food Struct. 2017, 14, 17-29. [CrossRef]

5. Lacroix, M.; Vu, K.D. Edible Coating and Film Materials. In Innovations in Food Packaging, 2nd ed.; A Volume in Food Science and Technology; Elsevier: Amsterdam, The Netherlands, 2014; pp. 277-304, ISBN 9780123946010.

6. Suput, D.; Lazic, V.; Popovic, S.; Hromis, N. Edible films and coatings: Sources, properties and application. Food Feed Res. 2015, 42, 11-22. [CrossRef]

7. Han, J.H. Edible Films and Coatings. In Innovations in Food Packaging, 2nd ed.; A Volume in Food Science and Technology; Elsevier: Amsterdam, The Netherlands, 2014; pp. 213-255.

8. Cinelli, P.; Schmid, M.; Bugnicourt, E.; Wildner, J.; Bazzichi, A.; Anguillesi, I.; Lazzeri, A. Whey protein layer applied on biodegradable packaging film to improve barrier properties while maintaining biodegradability. Polym. Degrad. Stab. 2014, 108, 151-157. [CrossRef]

9. Milani, J.M.; Tirgarian, B. An overview of edible protein-based packaging: Main sources, advantages, drawbacks, recent progressions and food applications. J. Packag. Technol. Res. 2020, 4, 103-115. [CrossRef]

10. Khwaldia, K.; Ferez, C.; Banon, S.; Desobry, S.; Hardy, J. Milk proteins for edible films and coatings. Crit. Rev. Food Sci. Nutr. 2004, 44, 239-251. [CrossRef]

11. Di Pierro, P.; Mariniello, L.; Giosafatto, V.L.; Esposito, M.; Sabbah, M.; Porta, R. Dairy whey protein-based edible films and coatings for food preservation. In Food Packaging and Preservation; Elsevier: Amsterdam, The Netherlands, 2018 ; pp. 439-456.

12. Schmid, M.; Müller, K. Whey protein-based packaging films and coatings. In Whey Proteins; Elsevier: Amsterdam, The Netherlands, 2019; pp. 407-437.

13. Henriques, M.; Gomes, D.; Pereira, C. Whey protein edible coatings: Recent developments and applications. In Emerging and Traditional Technologies for Safe, Healthy and Quality Food; Springer International Publishing: Cham, Switzerland, 2016; pp. 177-196, ISBN 978-3-319-24038-1.

14. Domínguez, R.; Barba, F.J.; Gómez, B.; Putnik, P.; Bursać Kovačević, D.; Pateiro, M.; Santos, E.M.; Lorenzo, J.M. Active packaging films with natural antioxidants to be used in meat industry: A review. Food Res. Int. 2018, 113, 93-101. [CrossRef]

15. Fernandes, L.M.; Guimarães, J.T.; Pimentel, T.C.; Esmerino, E.A.; Freitas, M.Q.; Carvalho, C.W.P.; Cruz, A.G.; Silva, M.C. Edible whey protein films and coatings added with prebiotic ingredients. In Agri-Food Industry Strategies for Healthy Diets and Sustainability; Elsevier: Amsterdam, The Netherlands, 2020; pp. 177-193.

16. Cagri, A.; Ustunol, Z.; Ryser, E.T. Antimicrobial edible films and coatings. J. Food Prot. 2004, 67, 833-848. [CrossRef] [PubMed]

17. Yadav, J.S.S.; Yan, S.; Pilli, S.; Kumar, L.; Tyagi, R.D.; Surampalli, R.Y. Cheese whey: A potential resource to transform into bioprotein, functional/nutritional proteins and bioactive peptides. Biotechnol. Adv. 2015, 33, 756-774. [CrossRef]

18. Jovanovi, S.; Bara, M.; Ma, O. Whey proteins-Properties and possibility of application. Mljekarstvo 2005, 55, 215-233.

19. Khaire, R.A.; Gogate, P.R. Whey Proteins. In Proteins: Sustainable Source, Processing and Applications; Elsevier Inc.: Amsterdam, The Netherlands, 2019; pp. 193-223, ISBN 9780128166956.

20. Krochta, J.; Perez-Gago, M. Formation and properties of whey protein films and coatings. In Protein-Based Films and Coatings; CRC Press: Boca Raton, FL, USA, 2002; pp. 159-180.

21. Bhattacharjee, C.; Nath, A.; Cassano, A.; Tahergorabi, R.; Chakraborty, S. Conventional macro- and micromolecules separation. In Food Waste Recovery; Elsevier: Amsterdam, The Netherlands, 2015; pp. 105-126.

22. Soazo, M.; Rubiolo, A.C.; Verdini, R.A. Effect of drying temperature and beeswax content on physical properties of whey protein emulsion films. Food Hydrocoll. 2011, 25, 1251-1255. [CrossRef]

23. Alcantara, C.R.; Rumsey, T.R.; Krochta, J.M. Drying rate effect on the properties of whey protein films. J. Food Process Eng. 1998, 21,387-405. [CrossRef]

24. Kaya, S.; Kaya, A. Microwave drying effects on properties of whey protein isolate edible films. J. Food Eng. 2000, 43, 91-96. [CrossRef]

25. Sothornvit, R.; Krochta, J.M. Plasticizers in edible films and coatings. In Innovations in Food Packaging; Academic Press: Cambridge, MA, USA, 2005; pp. 403-433. [CrossRef] 
26. Wang, C.; Killpatrick, A.; Humphrey, A.; Guo, M. Whey protein functional properties and applications in food formulation. In Whey Protein Production, Chemistry, Functionality, and Applications; John Wiley \& Sons, Ltd.: Chichester, UK, 2019; pp. 157-204, ISBN 9781119256052.

27. Dangaran, K.L.; Krochta, J.M. Whey protein films and coatings. In Whey Processing, Functionality and Health Benefits; Wiley: New York, NY, USA, 2008; ISBN 978-0-813-80903-8.

28. Schmid, M.; Reichert, K.; Hammann, F.; Stäbler, A. Storage time-dependent alteration of molecular interaction-property relationships of whey protein isolate-based films and coatings. J. Mater. Sci. 2015, 50, 4396-4404. [CrossRef]

29. Hernandez-Izquierdo, V.M.; Krochta, J.M. Thermoplastic processing of proteins for film formation-A Review. J. Food Sci. 2008, 73, R30-R39. [CrossRef]

30. Verbeek, C.J.R.; van den Berg, L.E. Extrusion processing and properties of protein-based thermoplastics. Macromol. Mater. Eng. 2010, 295, 10-21. [CrossRef]

31. Hernandez-Izquierdo, V.M.; Reid, D.S.; McHugh, T.H.; De J. Berrios, J.; Krochta, J.M. Thermal transitions and extrusion of glycerol-plasticized whey protein mixtures. J. Food Sci. 2008, 73, E169-E175. [CrossRef] [PubMed]

32. Sothornvit, R.; Olsen, C.W.; McHugh, T.H.; Krochta, J.M. Formation conditions, water-vapor permeability, and solubility of compression-molded whey protein films. J. Food Sci. 2003, 68, 1985-1999. [CrossRef]

33. Krochta, J.M. Proteins as raw materials for films and coatings: Definitions, current status, and opportunities. In Protein-Based Film and Coatings; CRC Press: Boca Raton, FL, USA, 2002; pp. 1-41.

34. Kim, S.-J.; Ustunol, Z. Solubility and moisture sorption isotherms of whey-protein-based edible films as influenced by lipid and plasticizer incorporation. J. Agric. Food Chem. 2001, 49, 4388-4391. [CrossRef] [PubMed]

35. Galietta, G.; Di Gioia, L.; Guilbert, S.; Cuq, B. Mechanical and thermomechanical properties of films based on whey proteins as affected by plasticizer and crosslinking agents. J. Dairy Sci. 1998, 81, 3123-3130. [CrossRef]

36. Sothornvit, R.; Krochta, J.M. Water vapor permeability and solubility of films from hydrolyzed whey protein. J. Food Sci. 2000, 65, 700-703. [CrossRef]

37. Pérez, L.M.; Piccirilli, G.N.; Delorenzi, N.J.; Verdini, R.A. Effect of different combinations of glycerol and/or trehalose on physical and structural properties of whey protein concentrate-based edible films. Food Hydrocoll. 2016, 56, 352-359. [CrossRef]

38. Sabato, S.F.; Ouattara, B.; Yu, H.; D'Aprano, G.; Le Tien, C.; Mateescu, M.A.; Lacroix, M. Mechanical and barrier properties of cross-linked soy and whey protein based films. J. Agric. Food Chem. 2001, 49, 1397-1403. [CrossRef]

39. Yoo, S.; Krochta, J.M. Whey protein-polysaccharide blended edible film formation and barrier, tensile, thermal and transparency properties. J. Sci. Food Agric. 2011, 91, 2628-2636. [CrossRef]

40. Brindle, L.P.; Krochta, J.M. Physical properties of whey protein-hydroxypropylmethylcellulose blend edible films. J. Food Sci. 2008, 73, E446-E454. [CrossRef] [PubMed]

41. Muñoz, L.A.; Aguilera, J.M.; Rodriguez-Turienzo, L.; Cobos, A.; Diaz, O. Characterization and microstructure of films made from mucilage of Salvia hispanica and whey protein concentrate. J. Food Eng. 2012, 111, 511-518. [CrossRef]

42. Basiak, E.; Lenart, A.; Debeaufort, F. Effects of carbohydrate/protein ratio on the microstructure and the barrier and sorption properties of wheat starch-whey protein blend edible films. J. Sci. Food Agric. 2017, 97, 858-867. [CrossRef]

43. Anker, M.; Berntsen, J.; Hermansson, A.M.; Stading, M. Improved water vapor barrier of whey protein films by addition of an acetylated monoglyceride. Innov. Food Sci. Emerg. Technol. 2002, 3, 81-92. [CrossRef]

44. Reinoso, E.; Mittal, G.S.; Lim, L.-T. Influence of Whey Protein Composite Coatings on Plum (Prunus Domestica L.) Fruit Quality. Food Bioprocess Technol. 2008, 1, 314-325. [CrossRef]

45. Janjarasskul, T.; Rauch, D.J.; McCarthy, K.L.; Krochta, J.M. Barrier and tensile properties of whey protein-candelilla wax film/sheet. LWT-Food Sci. Technol. 2014, 56, 377-382. [CrossRef]

46. Galus, S.; Kadzińska, J. Whey protein edible films modified with almond and walnut oils. Food Hydrocoll. 2016, 52, 78-86. [CrossRef]

47. Ustunol, Z.; Mert, B. Water solubility, mechanical, barrier, and thermal properties of cross-linked whey protein isolate-based films. J. Food Sci. 2006, 69, FEP129-FEP133. [CrossRef]

48. Schmid, M.; Sängerlaub, S.; Wege, L.; Stäbler, A. Properties of transglutaminase crosslinked whey protein isolate coatings and cast films. Packag. Technol. Sci. 2014, 27, 799-817. [CrossRef]

49. Rossi Marquez, G.; Di Pierro, P.; Esposito, M.; Mariniello, L.; Porta, R. Application of transglutaminase-crosslinked whey protein/pectin films as water barrier coatings in fried and baked foods. Food Bioprocess Technol. 2014, 7, 447-455. [CrossRef]

50. Han, J. Protein-based edible films and coatings carrying antimicrobial agents. In Protein-Based Films and Coatings; CRC Press: Boca Raton, FL, USA, 2002; pp. 485-499, ISBN 978-1-58716-107-0.

51. Ramos, Ó.L.; Pereira, J.O.; Silva, S.I.; Fernandes, J.C.; Franco, M.I.; Lopes-da-Silva, J.A.; Pintado, M.E.; Malcata, F.X. Evaluation of antimicrobial edible coatings from a whey protein isolate base to improve the shelf life of cheese. J. Dairy Sci. 2012, 95, 6282-6292. [CrossRef] [PubMed]

52. Ko, S.; Janes, M.E.; Hettiarachchy, N.S.; Johnson, M.G. Physical and Chemical Properties of Edible Films Containing Nisin and Their Action Against Listeria Monocytogenes. J. Food Sci. 2001, 66, 1006-1011. [CrossRef]

53. Cagri, A.; Ustunol, Z.; Ryser, E.T. Antimicrobial, mechanical, and moisture barrier properties of low ph whey protein-based edible films containing p-Aminobenzoic or Sorbic Acids. J. Food Sci. 2001, 66, 865-870. [CrossRef] 
54. Min, S.; Harris, L.J.; Krochta, J.M. Antimicrobial effects of lactoferrin, lysozyme, and the lactoperoxidase system and edible whey protein films incorporating the lactoperoxidase system against Salmonella enterica and Escherichia coli O157:H7. J. Food Sci. 2005, 70, m332-m338. [CrossRef]

55. Seydim, A.C.; Sarikus, G. Antimicrobial activity of whey protein based edible films incorporated with oregano, rosemary and garlic essential oils. Food Res. Int. 2006, 39, 639-644. [CrossRef]

56. Krochta, J.M. Milk protein film and coating application lab. In Manufacturing Whey; California Dairy Research Foundation, UC Davis: Davis, CA, USA, 2003.

57. Eswaranandam, S.; Hettiarachchy, N.S.; Johnson, M.G. Antimicrobial activity of citric, lactic, malic, or tartaric acids and nisinincorporated soy protein film against Listeria monocytogenes, Escherichia coli O157:H7, and Salmonella gaminara. J. Food Sci. 2006, 69, FMS79-FMS84. [CrossRef]

58. Oliveira, S.P.L.F.; Bertan, L.C.; De Rensis, C.M.V.B.; Bilck, A.P.; Vianna, P.C.B. Whey protein-based films incorporated with oregano essential oil. Polímeros 2017, 27, 158-164. [CrossRef]

59. Fernández-Pan, I.; Royo, M.; Ignacio Maté, J. Antimicrobial activity of whey protein isolate edible films with essential oils against food spoilers and foodborne pathogens. J. Food Sci. 2012, 77, M383-M390. [CrossRef]

60. Bahram, S.; Rezaei, M.; Soltani, M.; Kamali, A.; Ojagh, S.M.; Abdollahi, M. Whey Protein Concentrate Edible Film Activated with Cinnamon Essential Oil. J. Food Process. Preserv. 2014, 38, 1251-1258. [CrossRef]

61. Dawson, P.; Carl, G.; Acton, J.; Han, I. Effect of lauric acid and nisin-impregnated soy-based films on the growth of Listeria monocytogenes on turkey bologna. Poult. Sci. 2002, 81, 721-726. [CrossRef] [PubMed]

62. Min, S.; Rumsey, T.R.; Krochta, J.M. Diffusion of the antimicrobial lysozyme from a whey protein coating on smoked salmon. J. Food Eng. 2008, 84, 39-47. [CrossRef]

63. Neetoo, H.; Ye, M.; Chen, H. Potential antimicrobials to control Listeria monocytogenes in vacuum-packaged cold-smoked salmon pâté and fillets. Int. J. Food Microbiol. 2008, 123, 220-227. [CrossRef] [PubMed]

64. Gadang, V.P.; Hettiarachchy, N.S.; Johnson, M.G.; Owens, C. Evaluation of antibacterial activity of whey protein isolate coating incorporated with nisin, grape seed extract, malic acid, and EDTA on a turkey frankfurter system. J. Food Sci. 2008, 73, M389-M394. [CrossRef]

65. Boyac1, D.; Korel, F.; Yemenicioğlu, A. Development of activate-at-home-type edible antimicrobial films: An example pHtriggering mechanism formed for smoked salmon slices using lysozyme in whey protein films. Food Hydrocoll. 2016, 60, 170-178. [CrossRef]

66. Cagri, A.; Ustunol, Z.; Ryser, E.T. Inhibition of three pathogens on bologna and summer sausage using antimicrobial edible films. J. Food Sci. 2002, 67, 2317-2324. [CrossRef]

67. Cagri, A.; Ustunol, Z.; Osburn, W.; Ryser, E.T. Inhibition of Listeria monocytogenes on Hot Dogs Using Antimicrobial Whey Protein-based Edible Casings. J. Food Sci. 2003, 68, 291-299. [CrossRef]

68. Zinoviadou, K.G.; Koutsoumanis, K.P.; Biliaderis, C.G. Physical and thermo-mechanical properties of whey protein isolate films containing antimicrobials, and their effect against spoilage flora of fresh beef. Food Hydrocoll. 2010, 24, 49-59. [CrossRef]

69. Badr, K.R.; Ahmed, Z.S.; ElGamal, M.S. Evaluation of the antimicrobial action of whey protein edible films incorporated with cinnamon, cumin and thyme against spoilage flora of fresh beef. Int. J. Agric. Res. 2014, 9, 242-250. [CrossRef]

70. Soukoulis, C.; Behboudi-Jobbehdar, S.; Macnaughtan, W.; Parmenter, C.; Fisk, I.D. Stability of Lactobacillus rhamnosus GG incorporated in edible films: Impact of anionic biopolymers and whey protein concentrate. Food Hydrocoll. 2017, 70, 345-355. [CrossRef]

71. Beristain-Bauza, S.d.C.; Mani-López, E.; Palou, E.; López-Malo, A. Antimicrobial activity of whey protein films supplemented with Lactobacillus sakei cell-free supernatant on fresh beef. Food Microbiol. 2017, 62, 207-211. [CrossRef]

72. Gagliarini, N.; Diosma, G.; Garrote, G.L.; Abraham, A.G.; Piermaria, J. Whey protein-kefiran films as driver of probiotics to the gut. LWT 2019, 105, 321-328. [CrossRef]

73. Yang, L.; Paulson, A. Effects of lipids on mechanical and moisture barrier properties of edible gellan film. Food Res. Int. 2000, 33, 571-578. [CrossRef]

74. Sothornvit, R.; Krochta, J.M. Plasticizer effect on oxygen permeability of $\beta$-lactoglobulin films. J. Agric. Food Chem. 2000, 48, 6298-6302. [CrossRef] [PubMed]

75. Sothornvit, R.; Krochta, J.M. Plasticizer effect on mechanical properties of $\beta$-lactoglobulin films. J. Food Eng. 2001, 50, 149-155. [CrossRef]

76. Shaw, N.B.; Monahan, F.J.; O’Riordan, E.D.; O'Sullivan, M. Physical properties of wpi films plasticized with glycerol, xylitol, or sorbitol. J. Food Sci. 2002, 67, 164-167. [CrossRef]

77. Schmid, M.; Hinz, L.-V.; Wild, F.; Noller, K. Effects of hydrolysed whey proteins on the techno-functional characteristics of whey protein-based films. Materials 2013, 6, 927-940. [CrossRef] [PubMed]

78. Schmid, M. Properties of cast films made from different ratios of whey protein isolate, hydrolysed whey protein isolate and glycerol. Materials 2013, 6, 3254-3269. [CrossRef]

79. Hsu, C.-H.; Lu, J.-K.; Tsai, R.-J. Effects of low-temperature coating process on mechanical behaviors of ADI. Mater. Sci. Eng. A 2005, 398, 282-290. [CrossRef]

80. Tang, C.-H.; Jiang, Y. Modulation of mechanical and surface hydrophobic properties of food protein films by transglutaminase treatment. Food Res. Int. 2007, 40, 504-509. [CrossRef] 
81. Han, J.H.; Floros, J.D. Casting antimicrobial packaging films and measuring their physical properties and antimicrobial activity. J. Plast. Film Sheeting 1997, 13, 287-298. [CrossRef]

82. Khanzadi, M.; Jafari, S.M.; Mirzaei, H.; Chegini, F.K.; Maghsoudlou, Y.; Dehnad, D. Physical and mechanical properties in biodegradable films of whey protein concentrate-pullulan by application of beeswax. Carbohydr. Polym. 2015, 118, 24-29. [CrossRef]

83. Wagh, Y.R.; Pushpadass, H.A.; Emerald, F.M.E.; Nath, B.S. Preparation and characterization of milk protein films and their application for packaging of Cheddar cheese. J. Food Sci. Technol. 2014, 51, 3767-3775. [CrossRef] [PubMed]

84. Di Pierro, P.; Sorrentino, A.; Mariniello, L.; Giosafatto, C.V.L.; Porta, R. Chitosan/whey protein film as active coating to extend Ricotta cheese shelf-life. LWT_Food Sci. Technol. 2011, 44, 2324-2327. [CrossRef]

85. Cisneros-Zevallos, L.A.; Krochta, J.M. Whey protein coatings delay ripening of banana fruits. In Book of Abstracts, Proceedings of the IFT Annual Meeting, Atlanta, GA, USA, 20-24 June 1998; Institute of Food Technologists: Chicago, IL, USA, 1998.

86. Cisneros-Zevallos, L.; Krochta, J.M. Whey Protein Coatings for Fresh. JFS Food Eng. Phys. Prop. 2003, 68, $176-181$.

87. Perez-Gago, M.B.; Serra, M.; del Río, M.A. Color change of fresh-cut apples coated with whey protein concentrate-based edible coatings. Postharvest Biol. Technol. 2006, 39, 84-92. [CrossRef]

88. Feng, Z.; Wu, G.; Liu, C.; Li, D.; Jiang, B.; Zhang, X. Edible coating based on whey protein isolate nanofibrils for antioxidation and inhibition of product browning. Food Hydrocoll. 2018, 79, 179-188. [CrossRef]

89. Rossi Marquez, G.; Di Pierro, P.; Mariniello, L.; Esposito, M.; Giosafatto, C.V.L.; Porta, R. Fresh-cut fruit and vegetable coatings by transglutaminase-crosslinked whey protein/pectin edible films. LWT 2017, 75, 124-130. [CrossRef]

90. Tzoumaki, M.V.; Biliaderis, C.G.; Vasilakakis, M. Impact of edible coatings and packaging on quality of white asparagus (Asparagus officinalis, L.) during cold storage. Food Chem. 2009, 117, 55-63. [CrossRef]

91. Huang, L.; Zhang, M.; Yan, W.; Mujumdar, A.S.; Sun, D. Effect of coating on post-drying of freeze-dried strawberry pieces. J. Food Eng. 2009, 92, 107-111. [CrossRef]

92. Galus, S.; Mikus, M.; Ciurzyńska, A.; Domian, E.; Kowalska, J.; Marzec, A.; Kowalska, H. The effect of whey protein-based edible coatings incorporated with lemon and lemongrass essential oils on the quality attributes of fresh-cut pears during storage. Coatings 2021, 11, 745. [CrossRef]

93. Hassani, F.; Garousi, F.; Javanmard, M. Edible coating based on whey protein concentrate-rice bran oil to maintain the physical and chemical properties of the kiwifruit (Actinidia deliciosa). Research 2012, 10, 26-34.

94. Abedi, A.; Lakzadeh, L.; Amouheydari, M. Effect of an edible coating composed of whey protein concentrate and rosemary essential oil on the shelf life of fresh spinach. J. Food Process. Preserv. 2021, 45, e15284. [CrossRef]

95. De Araújo Soares, R.; Borges, S.V.; Dias, M.V.; Piccoli, R.H.; Fassani, E.J.; Silva, E.M.C. da Impact of whey protein isolate/sodium montmorillonite/sodium metabisulfite coating on the shelf life of fresh eggs during storage. LWT 2021, 139, 110611. [CrossRef]

96. Zinoviadou, K.G.; Koutsoumanis, K.P.; Biliaderis, C.G. Physico-chemical properties of whey protein isolate films containing oregano oil and their antimicrobial action against spoilage flora of fresh beef. Meat Sci. 2009, 82, 338-345. [CrossRef]

97. Mukherjee, D.; Haque, Z.Z.; Promotion, H.; Promotion, H. Reduced protein carbonylation of cube steak and catfish fillet. Ann. Food Sci. Technol. 2016, 17, 529-536.

98. Andrade, M.A.; Barbosa, C.H.; Souza, V.G.L.; Coelhoso, I.M.; Reboleira, J.; Bernardino, S.; Ganhão, R.; Mendes, S.; Fernando, A.L.; Vilarinho, F.; et al. Novel active food packaging films based on whey protein incorporated with seaweed extract: Development, characterization, and application in fresh poultry meat. Coatings 2021, 11, 229. [CrossRef]

99. Alcantra, C.R.; Krochta, J.M. Mechanical properties of wheyprotein-isolate-coated freeze-dried chicken white meat dice. In Book of Abstracts, Proceedings of the IFT Annual Meeting, Atlanta, GA, USA, 22-26 June 1996; Institute of Food Technologists: Chicago, IL, USA, 1996.

100. Molayi, R.; Ehsani, A.; Yousefi, M. The antibacterial effect of whey protein-alginate coating incorporated with the lactoperoxidase system on chicken thigh meat. Food Sci. Nutr. 2018, 6, 878-883. [CrossRef]

101. Brink, I.; Šipailienè, A.; Leskauskaitè, D. Antimicrobial properties of chitosan and whey protein films applied on fresh cut turkey pieces. Int. J. Biol. Macromol. 2019, 130, 810-817. [CrossRef] [PubMed]

102. Catarino, M.D.; Alves-Silva, J.M.; Fernandes, R.P.; Gonçalves, M.J.; Salgueiro, L.R.; Henriques, M.F.; Cardoso, S.M. Development and performance of whey protein active coatings with Origanum virens essential oils in the quality and shelf life improvement of processed meat products. Food Control 2017, 80, 273-280. [CrossRef]

103. Stuchell, Y.M.; Krochta, J.M. Edible coatings on frozen king salmon: Effect of whey protein isolate and acetylated monoglycerides on moisture loss and lipid oxidation. J. Food Sci. 1995, 60, 28-31. [CrossRef]

104. Costa, M.P.; Balthazar, C.F.; Rodrigues, B.L.; Lazaro, C.A.; Silva, A.C.O.; Cruz, A.G.; Conte Junior, C.A. Determination of biogenic amines by high-performance liquid chromatography (HPLC-DAD) in probiotic cow's and goat's fermented milks and acceptance. Food Sci. Nutr. 2015, 3, 172-178. [CrossRef]

105. Seyfzadeh, M.; Motalebi, A.A.; Kakoolaki, S.; Gholipour, H. Chemical, microbiological and sensory evaluation of gutted kilka coated with whey protein based edible film incorporated with sodium alginate during frozen storage. Iran. J. Fish. Sci. 2013, $12,140-153$.

106. Shokri, S.; Ehsani, A.; Jasour, M.S. Efficacy of lactoperoxidase system-whey protein coating on shelf-life extension of rainbow trout fillets during cold storage $\left(4^{\circ} \mathrm{C}\right)$. Food Bioprocess Technol. 2015, 8, 54-62. [CrossRef] 
107. Tokur, B.K.; Sert, F.; Aksun, E.T.; Özoğul, F. The Effect of Whey Protein Isolate Coating Enriched with Thyme Essential Oils on Trout Quality at Refrigerated Storage $\left(4 \pm 2{ }^{\circ} \mathrm{C}\right)$. J. Aquat. Food Prod. Technol. 2016, 25, 585-596. [CrossRef]

108. Y1ld1z, P.O.; Yang1lar, F. Effects of Different Whey Protein Concentrate Coating on Selected Properties of Rainbow Trout (Oncorhynchus mykiss) During Cold Storage $\left(4^{\circ} \mathrm{C}\right)$. Int. J. Food Prop. 2016, 19, 2007-2015. [CrossRef]

109. Yıld1z, P.O.; Yang1lar, F. Effects of whey protein isolate based coating enriched with Zingiber officinale and Matricaria recutita essential oils on the quality of refrigerated rainbow trout. J. Food Saf. 2017, 37, e12341. [CrossRef]

110. Ribeiro-Santos, R.; de Melo, N.R.; Andrade, M.; Azevedo, G.; Machado, A.V.; Carvalho-Costa, D.; Sanches-Silva, A. Whey protein active films incorporated with a blend of essential oils: Characterization and effectiveness. Packag. Technol. Sci. 2018, 31, 27-40. [CrossRef]

111. Chollakup, R.; Pongburoos, S.; Boonsong, W.; Khanoonkon, N.; Kongsin, K.; Sothornvit, R.; Sukyai, P.; Sukatta, U.; Harnkarnsujarit, N. Antioxidant and antibacterial activities of cassava starch and whey protein blend films containing rambutan peel extract and cinnamon oil for active packaging. LWT 2020, 130, 109573. [CrossRef]

112. Lee, S.-Y.; Krochta, J.M. Accelerated Shelf Life Testing of Whey-Protein-Coated Peanuts Analyzed by Static Headspace Gas Chromatography. J. Agric. Food Chem. 2002, 50, 2022-2028. [CrossRef] [PubMed]

113. Rossi-Márquez, G.; Helguera, M.; Briones, M.; Dávalos-Saucedo, C.A.; Di Pierro, P. Edible coating from enzymatically reticulated whey protein-pectin to improve shelf life on roasted peanuts. Coatings 2021, 11, 329. [CrossRef]

114. Maté, J.I.; Saltveit, M.E.; Krochta, J.M. Peanut and Walnut Rancidity: Effects of Oxygen Concentration and Relative Humidity. J. Food Sci. 1996, 61, 465-469. [CrossRef]

115. Hosseini, H.; Yaghoubi Hamgini, E.; Jafari, S.M.; Bolourian, S. Improving the oxidative stability of sunflower seed kernels by edible biopolymeric coatings loaded with rosemary extract. J. Stored Prod. Res. 2020, 89, 101729. [CrossRef]

116. Javanmard, M. Shelf life of whey protein-coated pistachio kernel (Pistacia Vera 1.). J. Food Process Eng. 2008, 31, 247-259. [CrossRef]

117. Miller, K.S.; Upadhyaya, S.K.; Krochta, J.M. Permeability of d-Limonene in Whey Protein Films. J. Food Sci. 2008, 63, $244-247$. [CrossRef]

118. Albert, S.; Mittal, G.S. Comparative evaluation of edible coatings to reduce fat uptake in a deep-fried cereal product. Food Res. Int. 2002, 35, 445-458. [CrossRef]

119. Soukoulis, C.; Yonekura, L.; Gan, H.-H.; Behboudi-Jobbehdar, S.; Parmenter, C.; Fisk, I. Probiotic edible films as a new strategy for developing functional bakery products: The case of pan bread. Food Hydrocoll. 2014, 39, 231-242. [CrossRef] [PubMed]

120. Kandasamy, S.; Park, W.S.; Yoo, J.; Yun, J.; Kang, H.B.; Seol, K.H.; Oh, M.H.; Ham, J.S. Characterisation of fungal contamination sources for use in quality management of cheese production farms in Korea. Asian-Australas. J. Anim. Sci. 2019, 33, 1002-1011. [CrossRef]

121. Pintado, C.M.B.S.; Ferreira, M.A.S.S.; Sousa, I. Control of pathogenic and spoilage microorganisms from cheese surface by whey protein films containing malic acid, nisin and natamycin. Food Control 2010, 21, 240-246. [CrossRef]

122. Henriques, M.; Santos, G.; Rodrigues, A.; Gomes, D. Replacement of conventional cheese coatings by natural whey protein edible coatings with antimicrobial activity. J. Hyg. Eng. Des. 2013, 3, 34-47.

123. Kavas, G.; Kavas, N. The effects of mint (Mentha spicata) essential oil fortified edible films on the physical, chemical and microbiological characteristics of lor cheese. J. Food Agric. Environ. 2014, 12, 40-45.

124. Caner, C. Whey protein isolate coating and concentration effects on egg shelf life. J. Sci. Food Agric. 2005, 85, 2143-2148. [CrossRef]

125. Valencia, G.A.; Luciano, C.G.; Fritz, A.R.M. Polymers for agri-food applications. In Polymers for Agri-Food Applications; Springer: Cham, Switzerland, 2019; pp. 391-416. [CrossRef]

126. Shon, J.; Chin, K.B. Effect of whey protein coating on quality attributes of low-fat, aerobically packaged sausage during refrigerated storage. J. Food Sci. 2008, 73, C469-C475. [CrossRef] [PubMed]

127. Akcan, T.; Estévez, M.; Serdaroğlu, M. Antioxidant protection of cooked meatballs during frozen storage by whey protein edible films with phytochemicals from Laurus nobilis L. and Salvia officinalis. LWT 2017, 77, 323-331. [CrossRef]

128. Rodriguez-Turienzo, L.; Cobos, A.; Moreno, V.; Caride, A.; Vieites, J.M.; Diaz, O. Whey protein-based coatings on frozen Atlantic salmon (Salmo salar): Influence of the plasticiser and the moment of coating on quality preservation. Food Chem. 2011, 128, 187-194. [CrossRef] [PubMed]

129. Hasanzati Rostami, A.; Motallebi, A.A.; Khanipour, A.A.; Soltani, M.; Khanedan, N. Effect of whey protein coating on PhysicChemical properties of gutted Kilka during frozen storage. Iran. J. Fish. Sci. 2010, 9, 412-421.

130. Rodriguez-Turienzo, L.; Cobos, A.; Diaz, O. Effects of microbial transglutaminase added edible coatings based on heated or ultrasound-treated whey proteins in physical and chemical parameters of frozen Atlantic salmon (Salmo salar). J. Food Eng. 2013, 119, 433-438. [CrossRef]

131. Tien, C.; Vachon, C.; Mateescu, M.-A.; Lacroix, M. Milk protein coatings prevent oxidative browning of apples and potatoes. J. Food Sci. 2001, 66, 512-516. [CrossRef]

132. Perez-Gago, M.B.; Serra, M.; Alonso, M.; Mateos, M.; del Río, M.A. Effect of whey protein- and hydroxypropyl methylcellulosebased edible composite coatings on color change of fresh-cut apples. Postharvest Biol. Technol. 2005, 36, 77-85. [CrossRef]

133. Gounga, M.E.; Xu, S.-Y.; Wang, Z.; Yang, W.G. Effect of whey protein isolate-pullulan edible coatings on the quality and shelf life of freshly roasted and freeze-dried chinese chestnut. J. Food Sci. 2008, 73, E155-E161. [CrossRef] [PubMed]

134. Soazo, M.; Pérez, L.M.; Rubiolo, A.C.; Verdini, R.A. Prefreezing application of whey protein-based edible coating to maintain quality attributes of strawberries. Int. J. Food Sci. Technol. 2015, 50, 605-611. [CrossRef] 
135. Han, J.H.; Hwang, H.-M.; Min, S.; Krochta, J.M. Coating of peanuts with edible whey protein film containing $\alpha$-tocopherol and ascorbyl palmitate. J. Food Sci. 2008, 73, E349-E355. [CrossRef] [PubMed]

136. Coltelli, M.-B.; Wild, F.; Bugnicourt, E.; Cinelli, P.; Lindner, M.; Schmid, M.; Weckel, V.; Müller, K.; Rodriguez, P.; Staebler, A.; et al State of the art in the development and properties of protein-based films and coatings and their applicability to cellulose based products: An Extensive Review. Coatings 2015, 6, 1. [CrossRef] 